\title{
دراسة جودة الخواص اللونية لبعض الصبغات الطبيعية \\ على أقمشة (السنجل جرسيه)
}

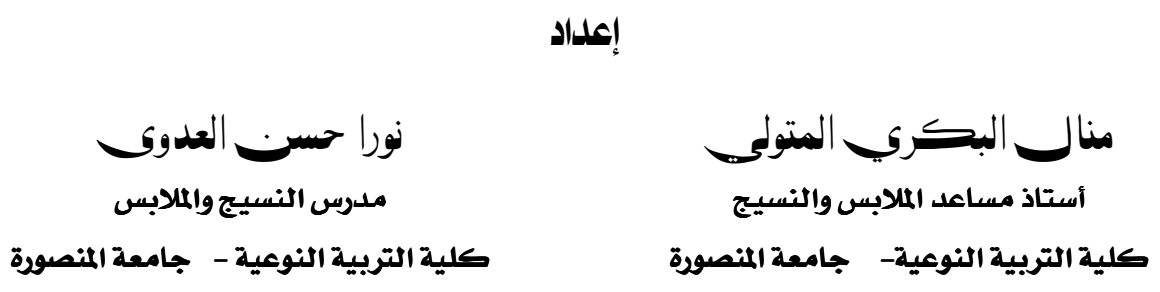

مجلة بحوث التربية النوعية ـ جامعة المنصورة

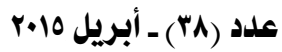


** د. نوراحسنالعدوى

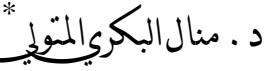

يهلدف البحث الحالي إلى دراسـة مدى إمكانية إنتاج أقمشـة طبيعية كليا باستخدلام صبغات

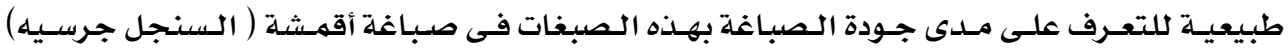

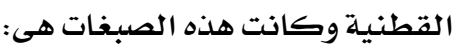

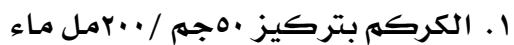

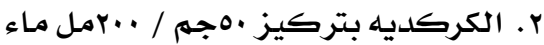

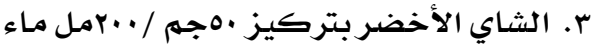

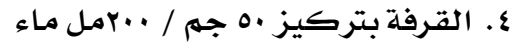

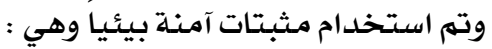

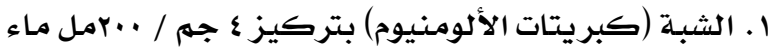

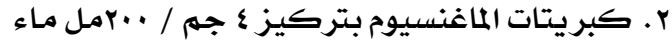

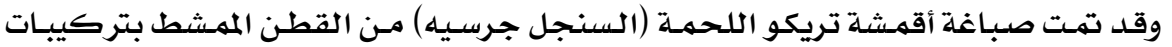

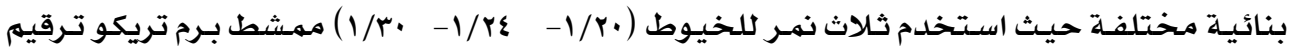

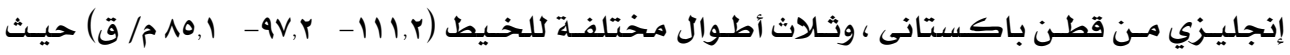

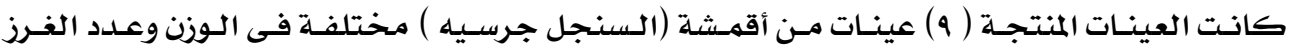

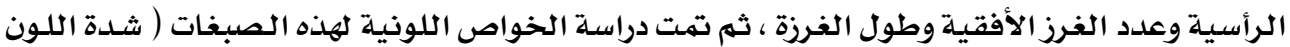

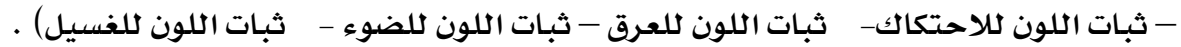
وكانت النتائج كالتالي:

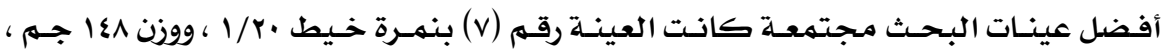

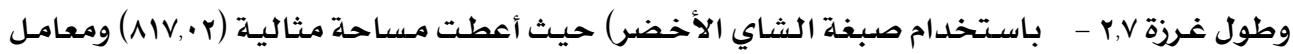

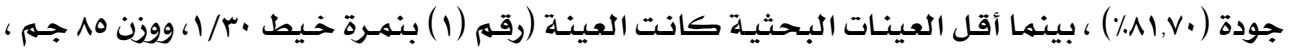

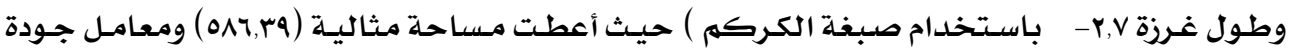

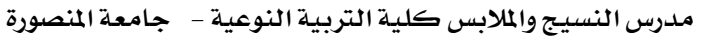


إن الغرض من الصباغة هو تحسين مظهرية الخامـة بإكسابها لون متجانس ليبقى ثابت ليا

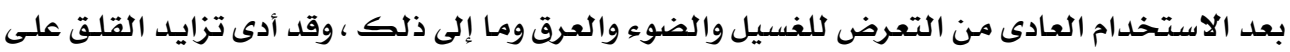

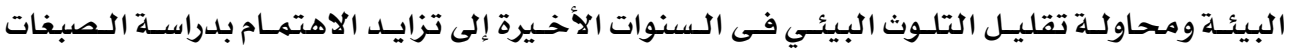

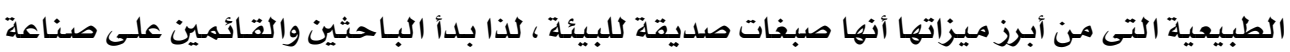

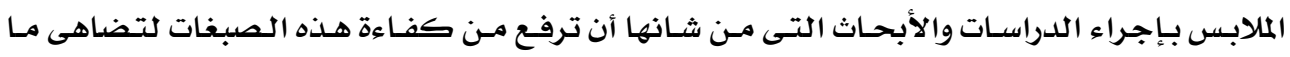

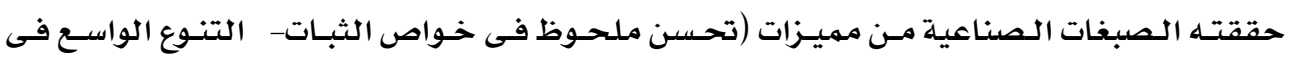
الألوان)

وقد بدأ استخدام الصبغات الطبيعية منذ العصر الحجرى وذلك بالحصول على الألوان من

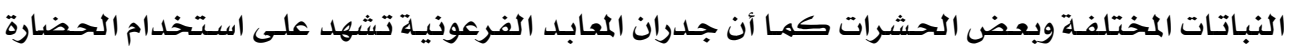

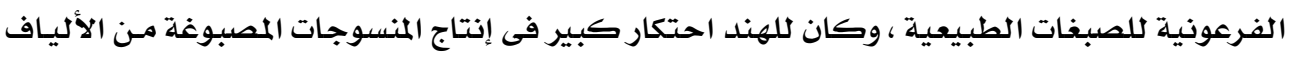

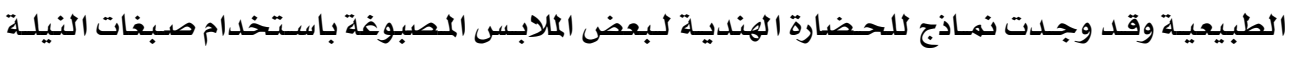

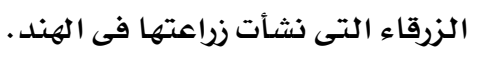

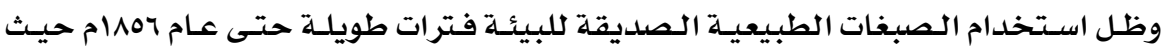

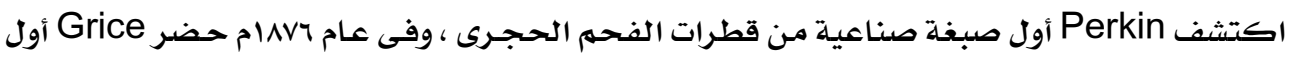

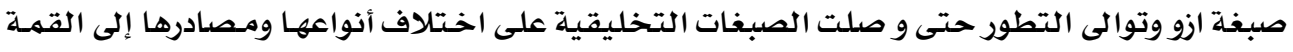

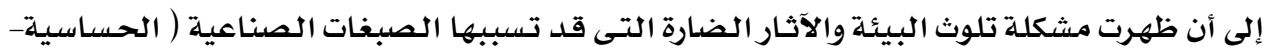

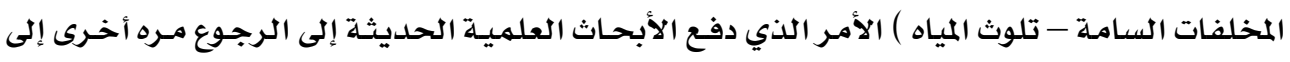
العودة إلى الصبغات الطبيعية للإقلال من الآثار البيئية.

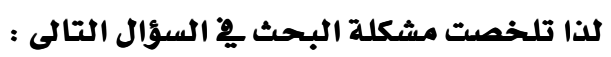

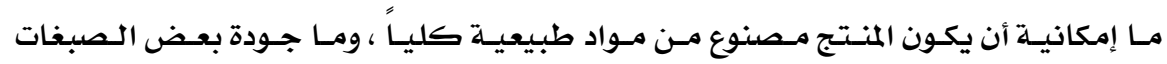

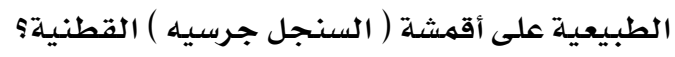

\section{ويتفرع من هذا التساؤل الرئيسى التساؤلات الفرعية التالية :}

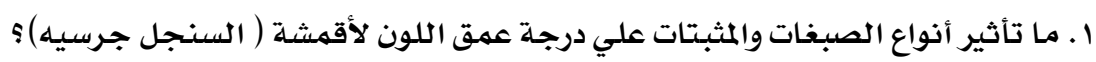

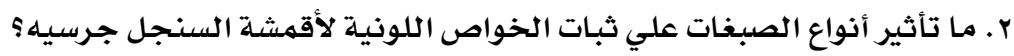

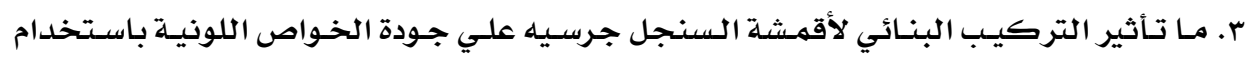

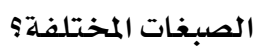

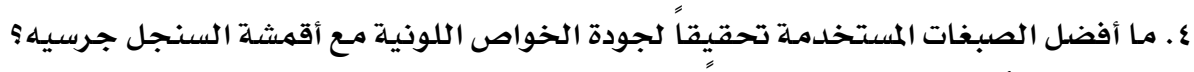

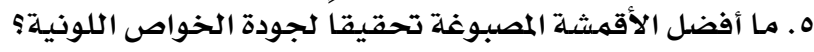




\section{أهميــة البحث:}

ا ـدراسـة مدى إمكانيـة إنتاج أقهشة طبيعية كلياً . r . التأكيد علي أهميـة الاتجاه نحو استخدام الصبـات الآمنسة بيئياً.

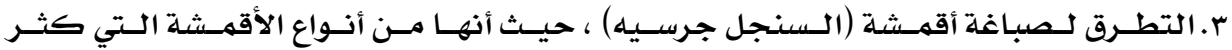

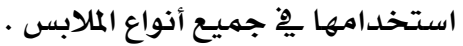

\section{أهداف البحث:}

ا ـ التعرف علي تأثير أنواع الصبغات والمثبـات علي درجة عهق اللون لأقهشة السنـل جرسيـه .

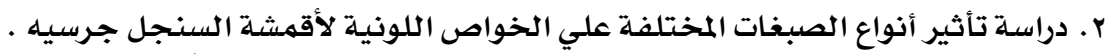
r. التوصل لأفضل التراكيب البنائيـة لأقهشة السنـجل جرسيــ تحقيقا لجـودة الخـواص اللونيـة باستخدام الصبغات المختلفة .

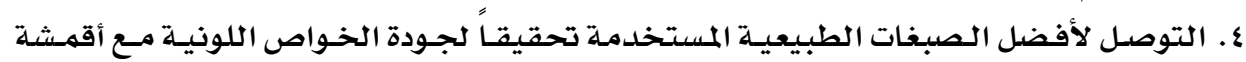

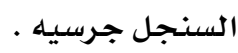
ه. التوصل لأفضل الأقهشة المصبوغة المبة تحقيقاً لجودة الخواص اللونية.

\section{فروض البحث:}

ا. توجلد علاقة ذات دلالة إحصائية بين نوع كل من ( الصبيخة - المثبت) والتأثير علي عمق اللون لأقهشة السنسجل جرسيـه.

r . توجد فروق ذات دلالة إحصائية بين أنواع الصبغات والخواص اللونية لأقمشة السنسجل جرسيـه.

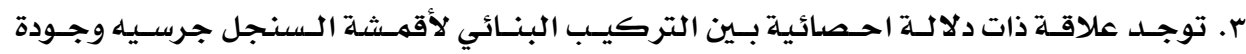
الخواص اللونية للصبغات الطبيعية. ع. توجد فروق ذات دلالهة إحصائية بين كل مـن (الـصبغات الطبيعيـة - العينـات البحثثيـة ) وجـودة الخواص اللونيـة .

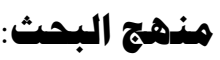

$$
\begin{aligned}
& \text { ا ـ المنهج الوصفى التحليلى. } \\
& \text { r. المنهج التجريبى. }
\end{aligned}
$$

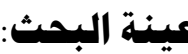

تكونت عينـة البحث من (و) عينات لأقهشة (السنـجل جرسيـه ) تختلف فِ خواصها البنائيـة

$$
\text { ومنتجـه من قماث قطن . . . . . }
$$


ا. استجابة التراكيب النسيجية القطنيـة للصباغة بالـصبفة الطبيعيـة(الحنـاء) بالمقارنـة بـصبفات الأحساض

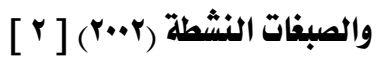

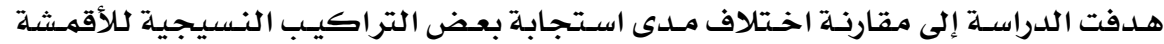

( سـادة - مبرد - تر يكو) لصنف جيزة rی للصبـاغة بالصبغات المختلفـة (طبيعيـة - أحسواض

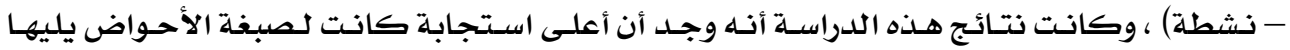
الصبغة الطبيعية ثم الصبغة النشطة ، وكذلك وجد أن النسيـج التريكو سجل أعلى استجابة للثلاث صبغخات يليها النسيـج السـادة ثم النسيـج المبرد وذلك يرجـع إلى طبيعيـة التركيـب النسسجي وطبيعـة تركيب الصببغة .

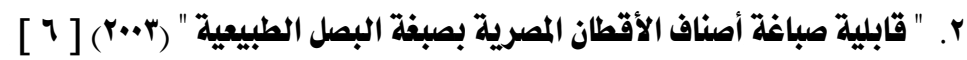

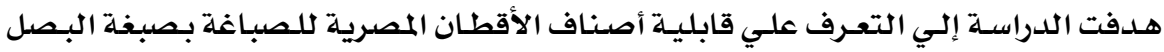

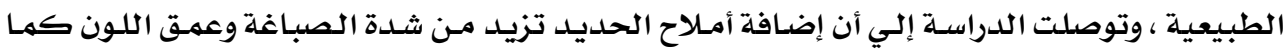
تعمل علي مقاومة الألوان للغسيل والضوء والعـرق .

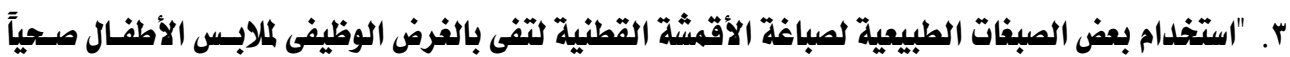
[بr [بيئيا")

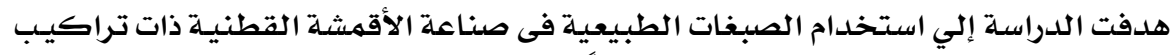

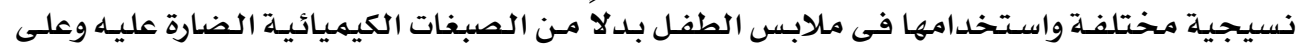
صحته مـن اجل المحافظة على مستوى عالى مـن الجودة . ع. " تأثير عمليات العناية على خواص بعض الأقمشة المصبوغة بالصبفات الطبيعية وإمكانية استخدامها في صناعة

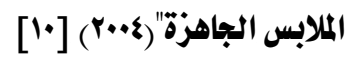

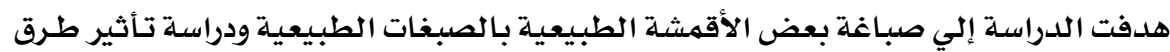

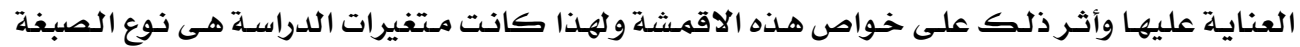

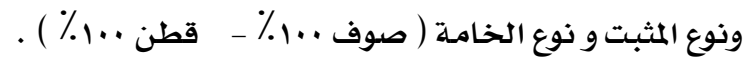


ه. " تحسين خواص الصباغة لـبعض أصسناف القطـن المـصري باسـتخدام صـبفة الكـركم الطبيعيـة مـع المعالجـة

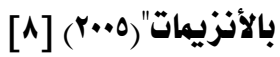

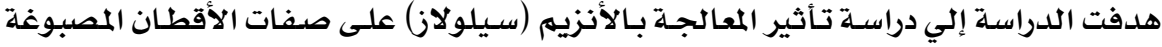

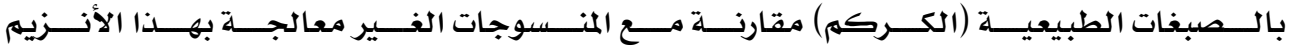

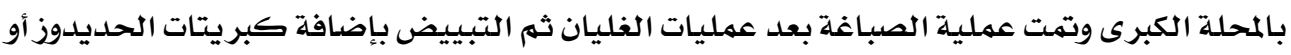

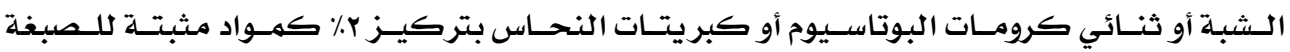

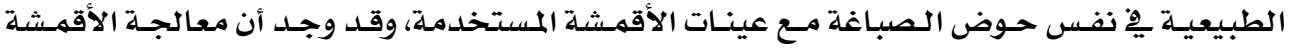

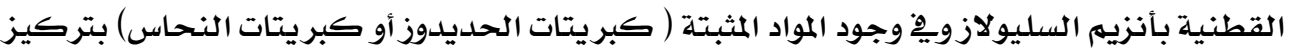

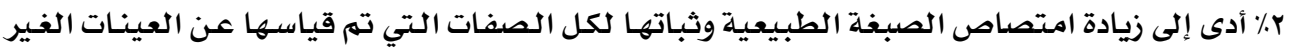
معالجـة بأنزيهم السليولاز.

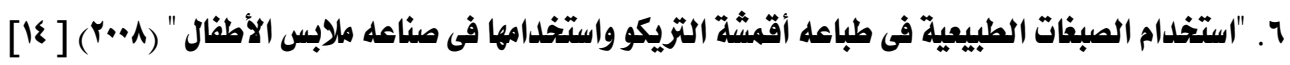
هدفت الدراسـة إلي الحصول على الصبغات الطبيعيـة مـن خـلال نباتات متاحسة ومتوفرة ـيخ

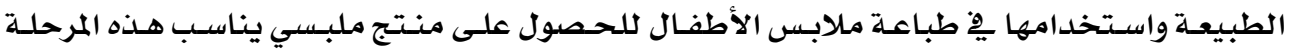

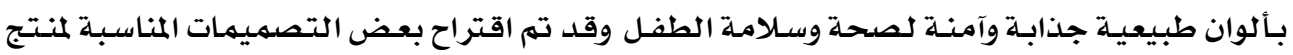
(التي شيرت) ويناسب مرحلة الطفولة.

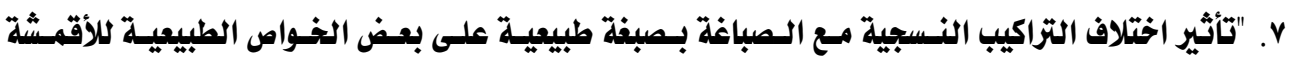

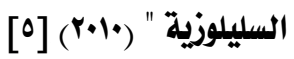

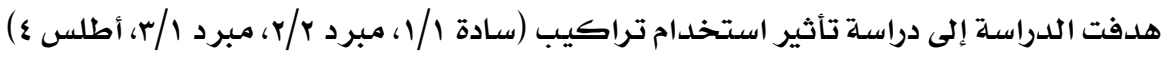

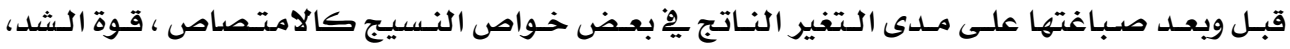

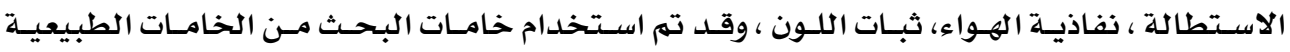

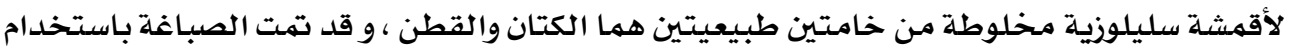

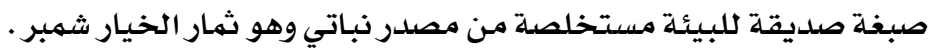

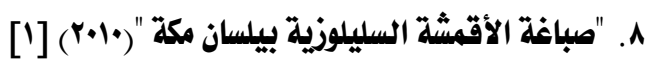

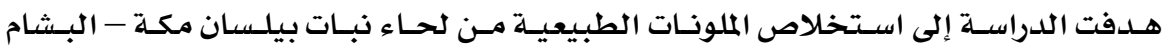

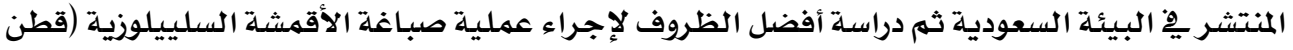

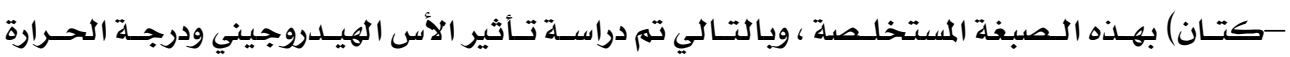

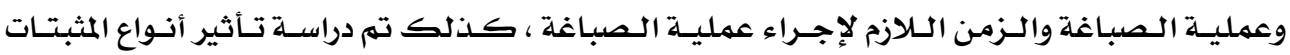

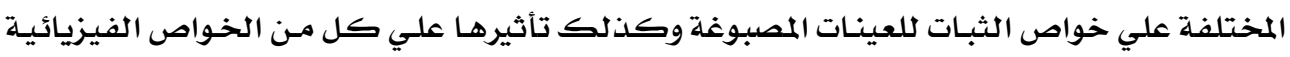

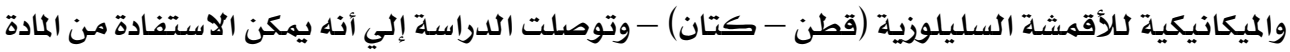

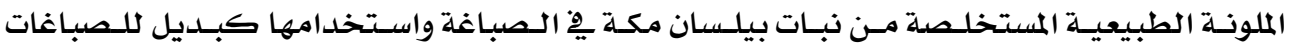




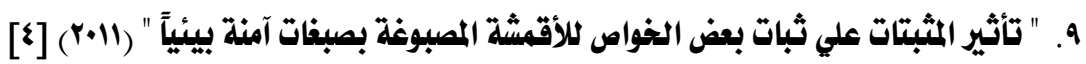

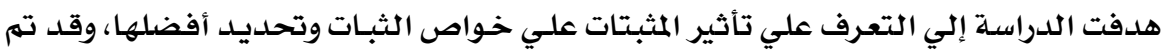

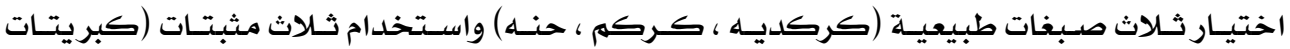

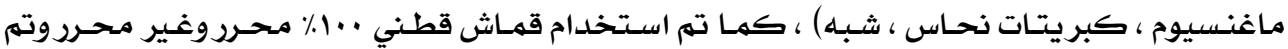

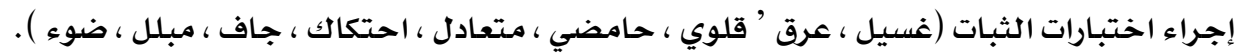

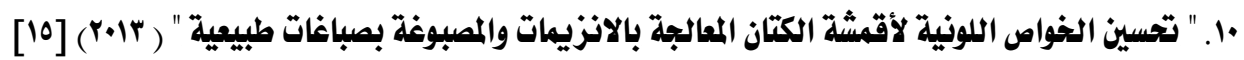

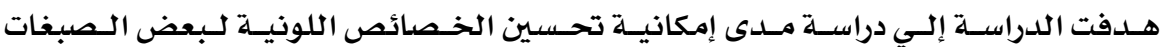
الطبيعية من خلال معالجة الكتان بالإنزيمات وذلك لتحسين خـواص أقمهشة الكتان وزيـادة قابليتها

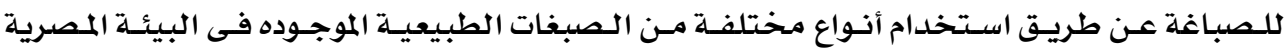

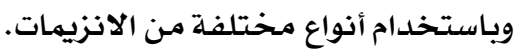

11. "Application of single and mixtures of red sandalwood and other natural dyes for dyeing of jute fabric: studies on colour arameters/colour fastness and compatibility "(2009) ) [17]

هدفت الدراسـة إلى استخدام صبغة خشب الصندل الأحمر الطبيعية بمفردها او بعد خلطها

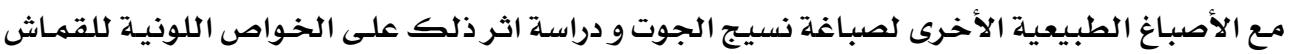

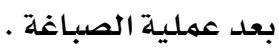

12. 'influence of gamma radiation on the colour strength and fastness properties of fabric using turmeric (Curcuma longa) as natural dye $e^{\prime \prime \prime \prime(2010)[25 ~] ~}$

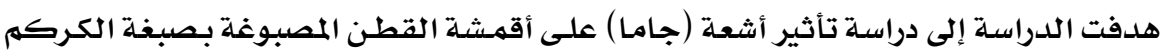

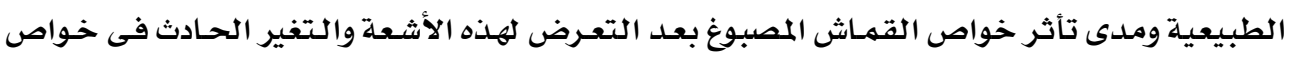

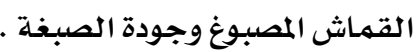

13. " Dyeing of Cotton Fabric Using UV Irradiated Turmeric (Curcuma longa L.) as Natural Dye"( 2011)[24]

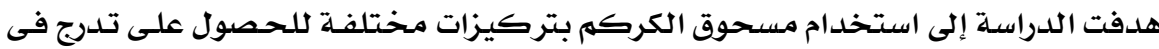

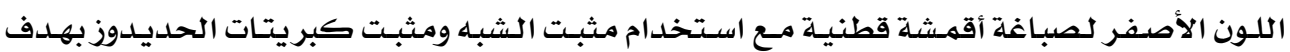

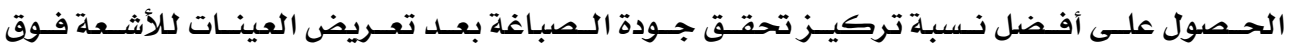




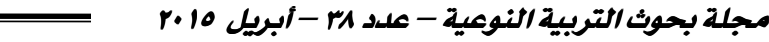

14. "Dyeing of $\gamma$-irradiated cotton with natural flavonoid dyeextracted from irradiated onion shells (Allium cepa) powder"(2013)[20 ]

هدفت الدراسـة إلى استخلـام صسبغة البــل فى صسباغة الخيوط القطنيـة المشعة بـاستخدام

مسستخلص ( الاديـوم) للتوصـل إلى مـلـى إمكانيـة تحسـين خـواص الـصبـاغة مـع الحـصول على أقمـشـة

مضادة للجراثيهم . مضرك

15. "Extraction of natural dye from red calico leaves: Gamma ray assisted improvements in colour strength and fastness properties"(2014))[16]

هدفت الدراسـة إلى دراسـة مدلى إمكانيـة استخدام الصبغـة الحمـراء المستخرجـة من أوراق نبات

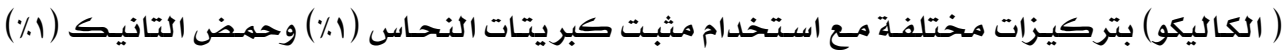

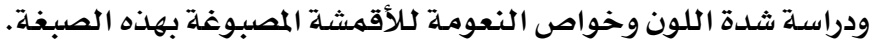

تعقمبب :

اسـفـاد البـحـث الحـالي مـن البـحـوث والدراسـات السسابقة فـى التعـرف على أفضل الظـروف

المناسبـة لصباغة الأقمشة القطنيـة وطريقة تجهيز العينات وكيفية استخخلاص الصبغة ، كمها سـاعد هٍِ اختياروتحديد المثبتات المناسبـة للصبغات موضـع الدراسـة.

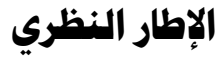

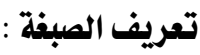

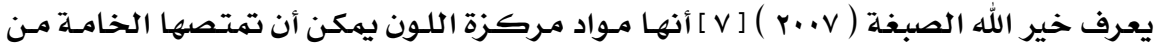

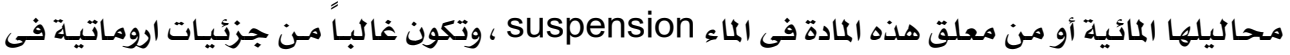

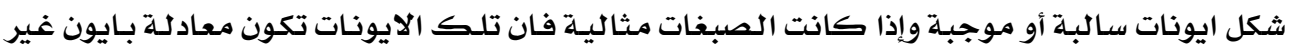
عضوي مخالف لها فى الشحنـة .

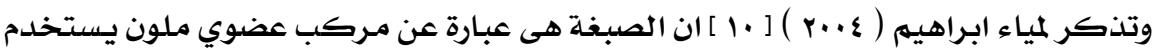
لإضفاء لون مـحلد علي مادة معروفة مثل صباغة المنسوجات ، وليس كل المركبـات العضوية تصلح كلاستخخدام كصبغات .

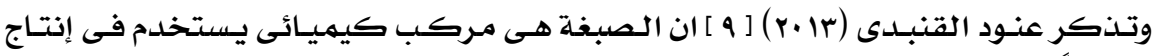

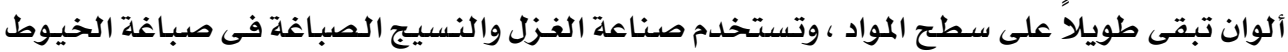
والأقمشـة كما تستخدم فى صبـاغة الفراء والجلد والورق والبـلاستيك.

نبذة تاريخية عن الصبفات الطبيعية :

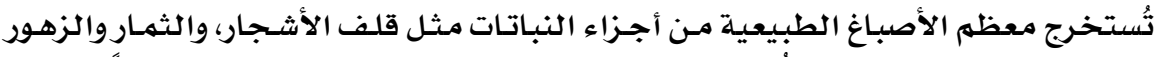

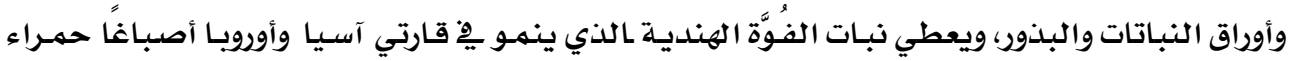

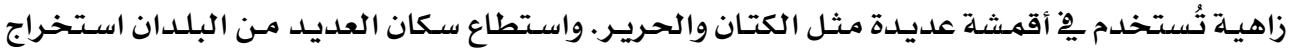

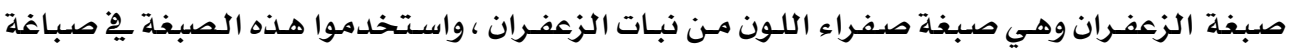




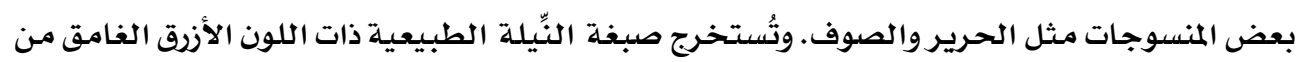

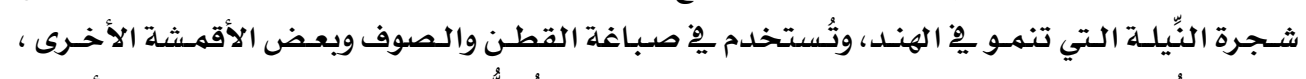

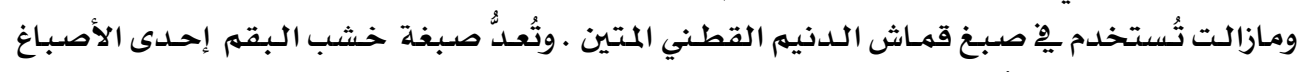

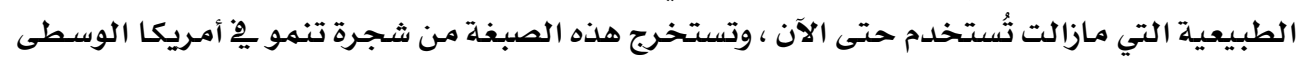

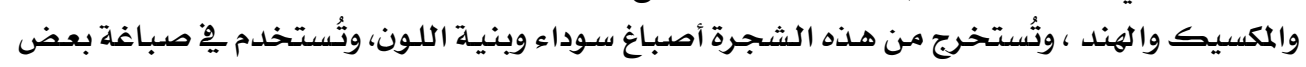

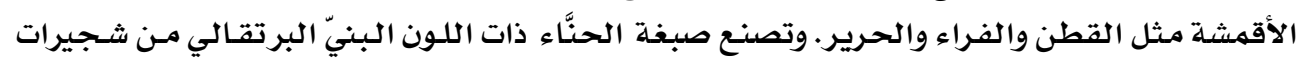

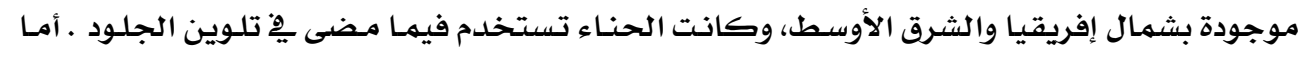

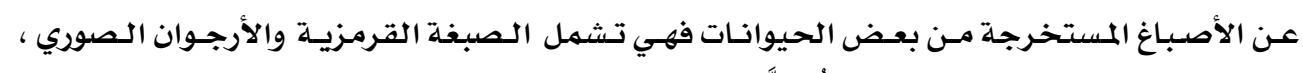

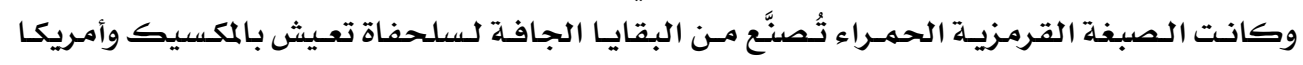

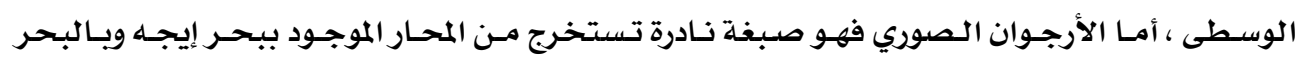

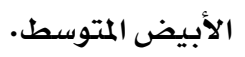

\section{ميززات الصبفات الطبيعية :}

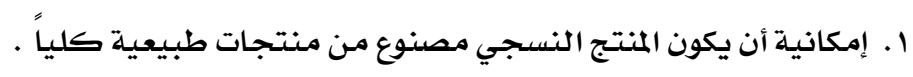

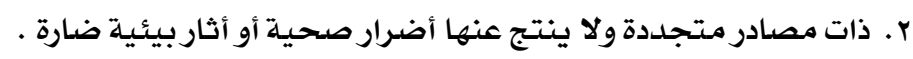

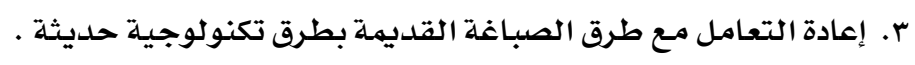

\section{عيوب الصبفات الطبيعية : ماده}

ا ـ قلـة المعرفـة الفنيـة بـشـان الطـرق المثلـى لاسـتخراج الـصبغات الطبيعيـة وكيفيـة اسـتخدامها

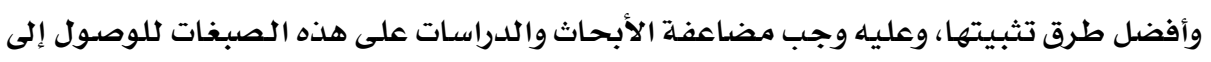

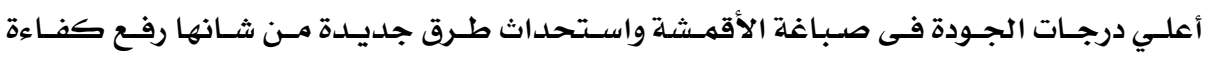

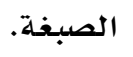

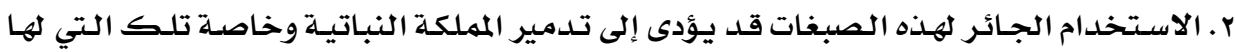

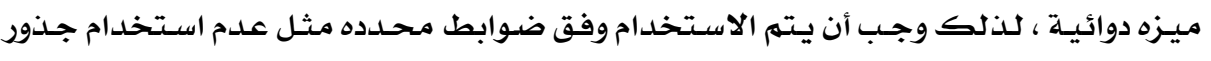

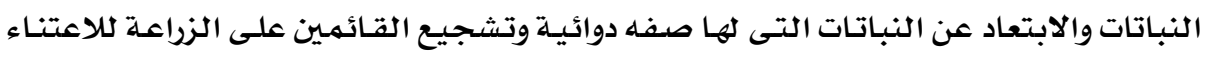

$$
\text { بمثل هذه المحاصيل وزيـادة الكميلة المزروعة. }
$$

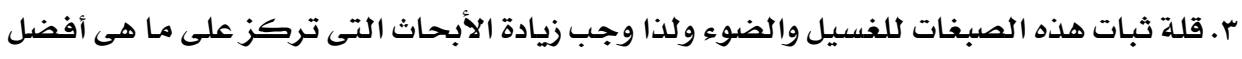

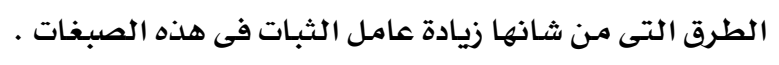

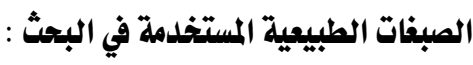

• صـبغة الكركديـة Roselle: تستخرج مـن شــيرة ذات أزهــار حمـراء جميلـة وتـزرع للزينـة أو

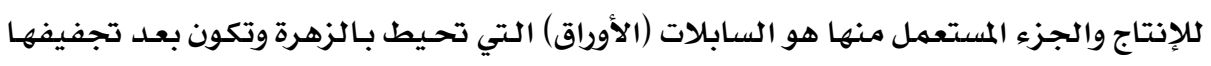

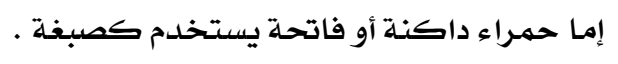

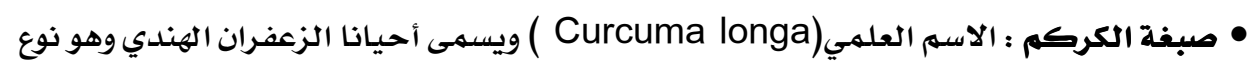

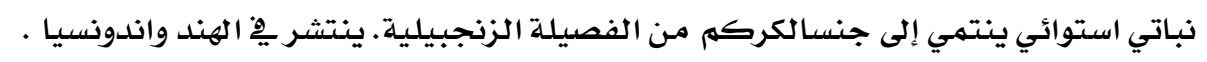

\section{r.}




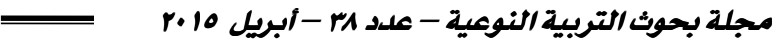

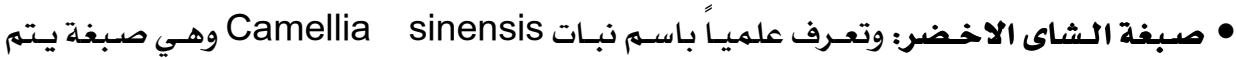

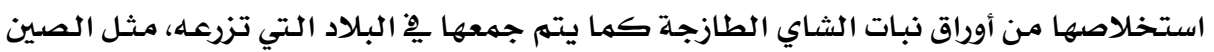

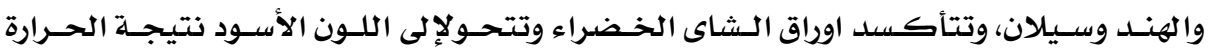
والرطوبة.

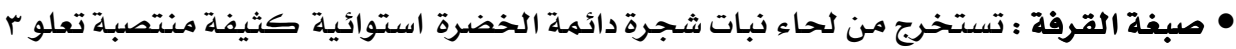

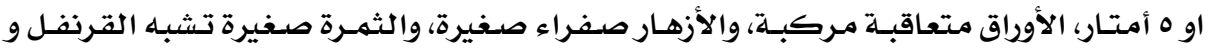

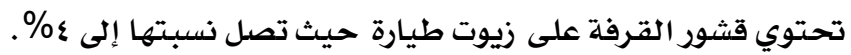

\section{نظريات الصباغة والعوامل التى تؤثر على عملية الصباغة :}

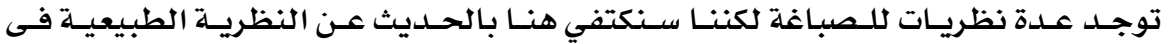

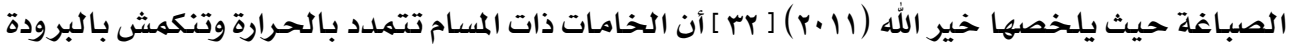

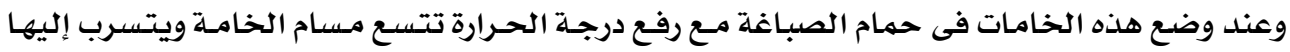

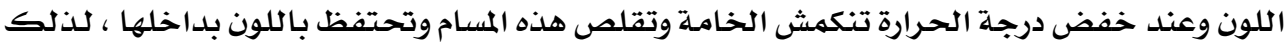

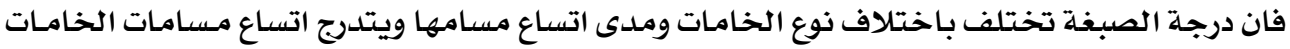

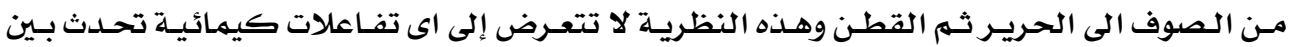
الصبغات والمواد المساعدة والخامـة المراد صبـاغتها.

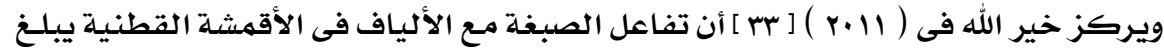

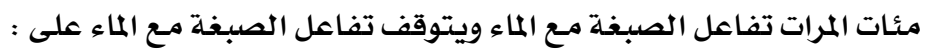

$$
\begin{aligned}
& \text { r- درجة الحرارة } \\
& \text { ع- طرق الصباغة الصراءة }
\end{aligned}
$$$$
\text { ا- امتصاص الصبغة }
$$

$$
\text { ب- م- ملوية الحمام }
$$

\section{الخواص اللونية للصبفة :}

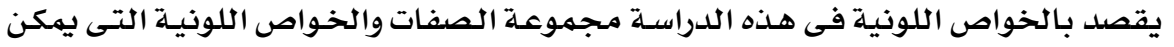

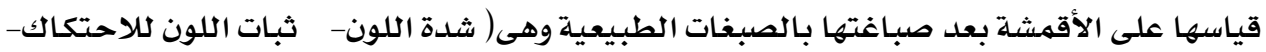

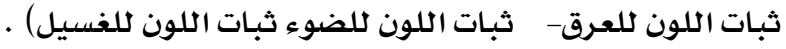
المثبتات :

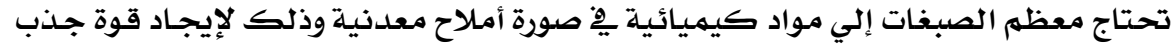

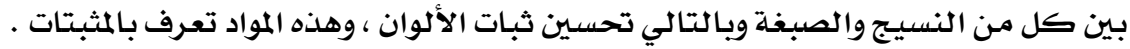




\section{ا ـ مثبت الشبيه Alum}

يذكر SK.Sharma (1991 ) [ سب ] أن الشبه هي مركب مزدوج من كبريتات الالومنيوم

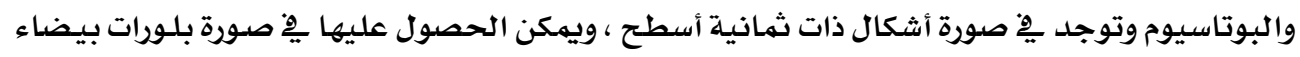

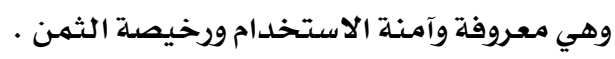

\section{r. مثبت كبريتات الماغنسيوم Magnesium sulfate}

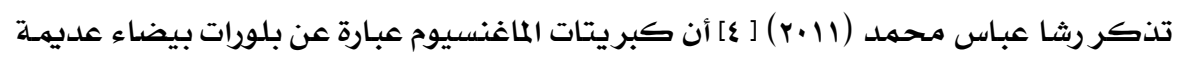

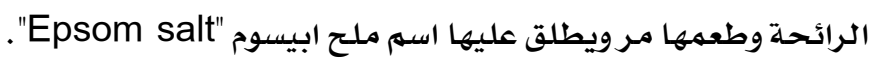
أقمشة السنجل جيرسي القطنية :

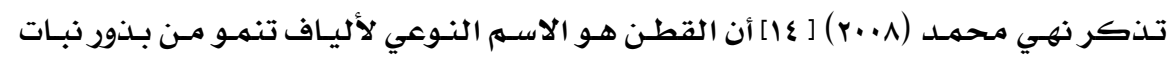

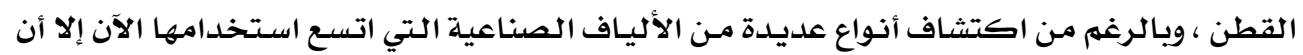

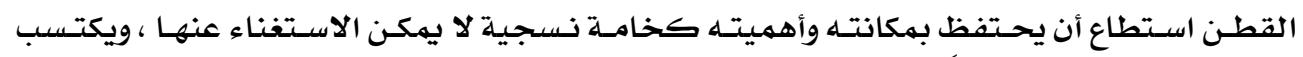

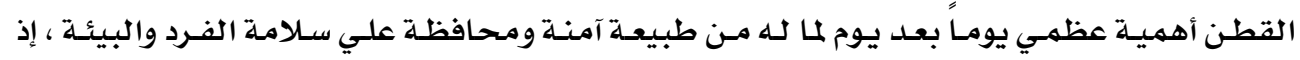

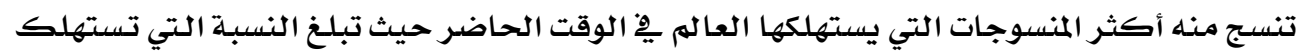

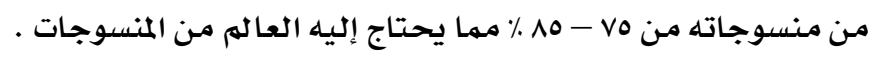

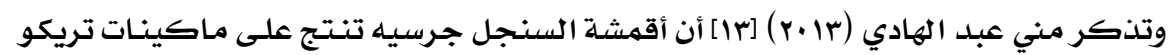

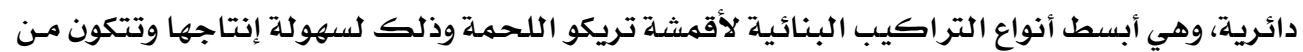

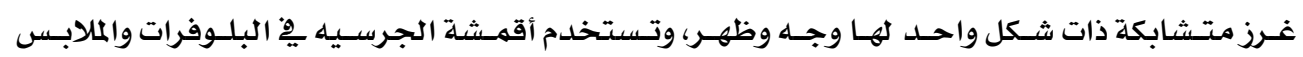

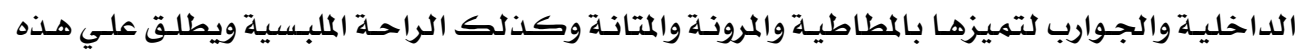

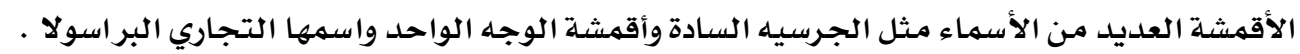

\section{أولاً : مواصفات العينات البحثية :}

تم إنتاج عينـات السنحل جرسـيه القطنيـة بالشركة المصرية للتريكو على ماكينـة تريكو

دائريـة جيج عr

جدول (1) يوضح مواصفات الماكينة جيج (ع) )

\begin{tabular}{|c|c|}
\hline ع أبره/ بوصة & اـ جيج الماكينة \\
\hline 7ץ بوصه & rـ قطر السلندر \\
\hline (19 إبره & بــ عدد الإبر \\
\hline 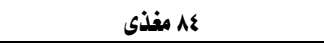 & كـ عدد المفذيات \\
\hline ذو السيوروالطارات & هـ جهاز التفذية الموجب \\
\hline Vا لفة / دقيقة أثناء عمل التجارب & 7ـ سرعة الماكينة \\
\hline
\end{tabular}




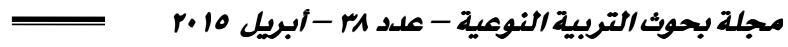

جدول (r) يوضح مواصفات العينات المستخدمة فى الدراسة

\begin{tabular}{|c|c|c|c|c|c|c|c|}
\hline عدد الفرز الأفقية & عدد الفرز الرأسية & طول الفرزه & طول الخيط & قوة شد الخيط & الوزن & نهرة الخيط & A \\
\hline$r$. & $r \Lambda, \Lambda$ & $r, Y$ & $M 11, r$ & $v, 0$ & 10 & $1 / r$. & 1 \\
\hline$r v, \Lambda$ & rA & 1,1 & ar, r & $\xi, 0$ & ar & $1 / r$. & r \\
\hline ro,r & $r V, r$ & $1, r$ & $\wedge 0,1$ & $r, 0$ & 117 & $1 / r$. & $r$ \\
\hline$r \cdot, \Lambda$ & rA & $r, r$ & $M I I, r$ & $v, 0$ & $11 \%$ & $1 / r \xi$ & $\varepsilon$ \\
\hline$\xi$ & YA, & 1,1 & $9 Y, r$ & $\xi, 0$ & $1 \xi$. & $1 / r \xi$ & 0 \\
\hline or, r & $r \xi, r$ & $1, r$ & $\wedge 0,1$ & $r, 0$ & 171 & $1 / r \xi$ & 9 \\
\hline$r r, \xi$ & rA & $r, Y$ & $M I, r$ & $v, 0$ & $1 \leqslant \wedge$ & $1 / r$. & v \\
\hline$\{r, \xi$ & rA & 1,1 & $q Y, r$ & $\xi, 0$ & IVA & $1 / r$. & $\wedge$ \\
\hline 07 & rq & $1, r$ & $\wedge 0,1$ & $r, 0$ & r.. & $1 / r$. & 9 \\
\hline
\end{tabular}

ثانياً : تجهيز العينات للصباغة :

تم تجهيز العينات بقطاع التجهيز بشركة مصر للغزل والنسيج بالمحلة الكبري علسي النحـو التالي:

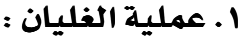

• تتم داخل غسالة اتوماتيك ، درجة الحرارة ، ·1 درجة مئوية ، الزمن ·ب دقيقة .

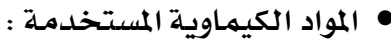

صودا كاوية بتركيز ·rجم / لتر

مواد مبللة (اسبيكون •r.1) بتركيز بجمه / لتر

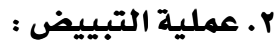

• درجة الحرارة +. إدرجة مئوية ، الزمن ·ب دقيقة

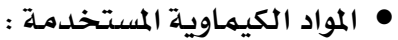

فوق أكسيد الهيدروجين بتركيز ·r جهم / لتر المبه سليكات صوديوم بتركيز ب جم / لتر

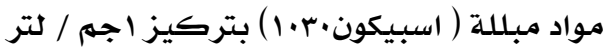

• ملحوظة : عملية التبييض للصباغة بلدون مواد تبييض ضوئي

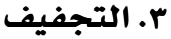

تم التجفيف داخل مجفف كهريائى على درجة حرارة +. 1 درجة مئوية لمدة · ب دقيقة. 
تم صـبـاغة العينـات بالـصبغات الطبيعيـة بقطـاع التجهيـز بــركة مـصر للغـزل والنسـيج

$$
\text { بالمحلة الكبري : }
$$

\section{الصبغات الطبيعية المستخلدمة :}

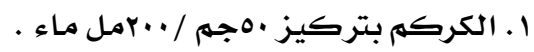

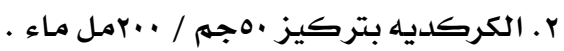

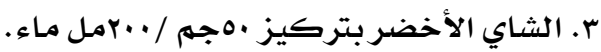

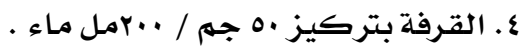

المثبتات المستخدمة :

تم استخدام مثبتات آمنـة بيئياً وهي :

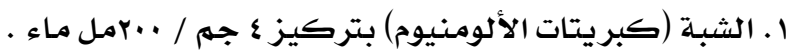

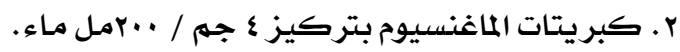

درجة الحرارة والزمن :

.9 درجة مئوية لمدة . ب دقيقة .

ا ـ استخلاص الصبغة :

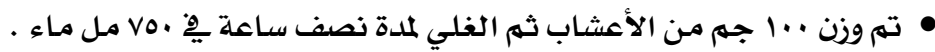

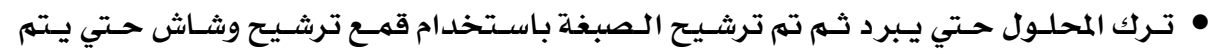

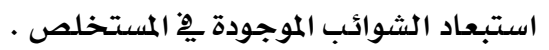

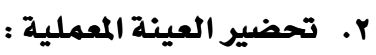

• تم وزن ه جم للعينات المراد صباغتها .

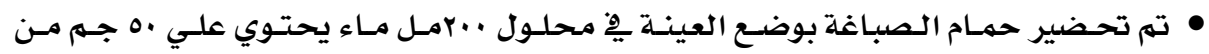

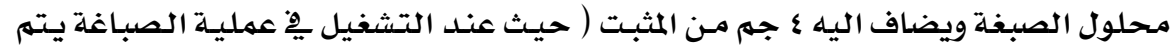

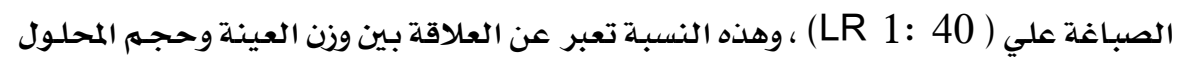

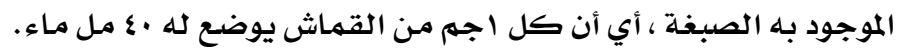

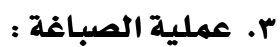

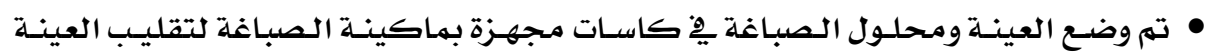

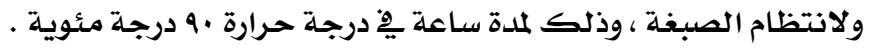




\section{اجراsات البحث :

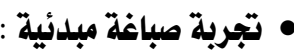

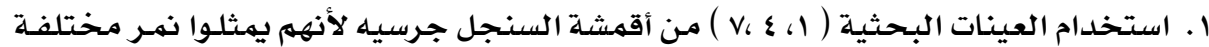

وأوزان مختلفة .

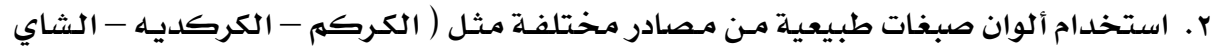

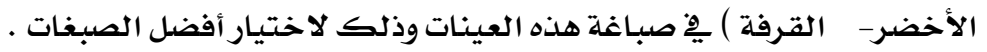

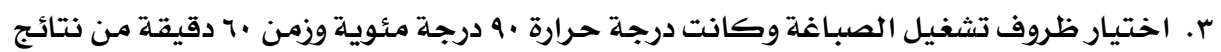

الأبحاث السابقة وكانت هذه أفضل الظروف لتشغيل الصبغات .

ع. استخدام كل من كبريتات الماغنسيوم والشبه كمثبتات للصبغات السابقة .

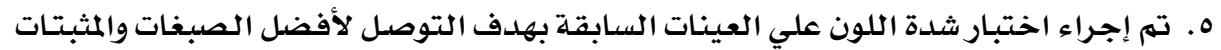

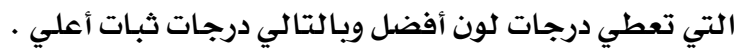

• ت تنفيذ صباغة العينات :

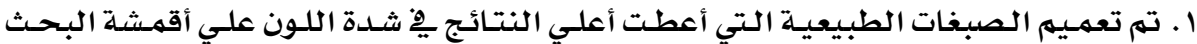

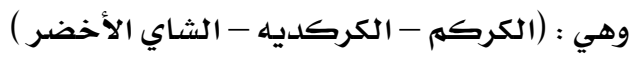

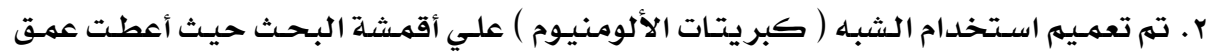

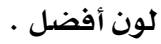

رابعاً : اختبارات الخواص اللونية علي العينات المصبوغة :

تم اجراء اختبارات الخواص اللونية للأقمشة بشركة مصر للغزل والنسيج بالمحلة الكبري وكانت كالتالي :

ا. اختبار قياس عمق اللوز (k/s) :

تم قياس شدة اللون للعينات المصبوغة تبعاً للطريقة القياسية [ 30] باستخدام جهاز (Model: S.F600+،, Data color International Spectro photometer)

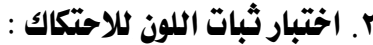

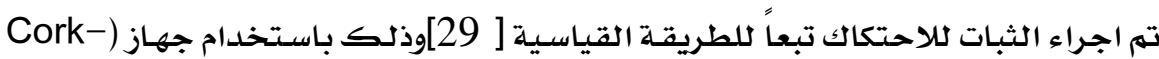
(meter

Dry Rubbing test اختبار الاحتكاك الجاف ونماف :

- اختبار الاحتكاك الرطب الاحتبال الجاف ل

وتم تقييم العينات باستخدام المقياس الرمادي (Gray scale) 


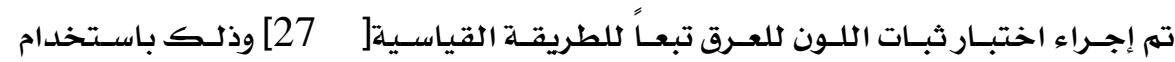
جهاز)

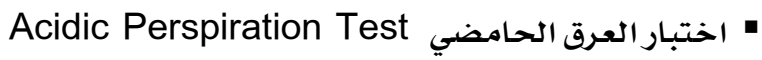

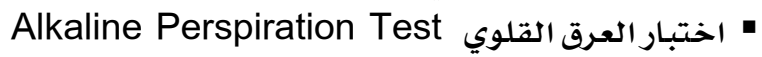
وتم تقييم العينات باستخدام المقياس الرمادي (Gray scale)

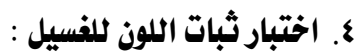

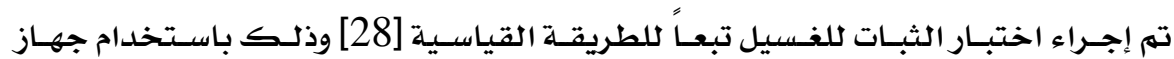
( Launder - meter standard Instrument) وتم تقييم مدي التغير بِّ لون العينات باستخدام المقياس الرمادي (Gray scale)

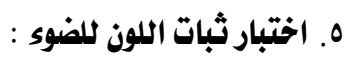

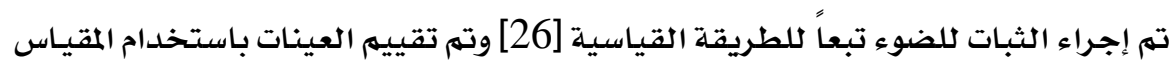

الأزرق ( Blue scale) تتائج قياس الخواص اللونية :

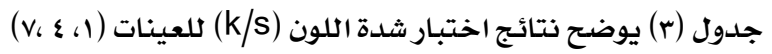
باستخدام الصبغات والمثبتات المختلفة

\begin{tabular}{|c|c|c|c|c|c|c|c|c|}
\hline \multicolumn{2}{|c|}{ القرفة } & \multicolumn{2}{|c|}{ الشاي الأخضر } & \multicolumn{2}{|c|}{ الكركلديه } & \multicolumn{2}{|c|}{ الكركم } & \multirow[t]{2}{*}{ العينة } \\
\hline كبريتات & الشبه & كبريتات & الشبه & كبريتات & الشبه & كبريتات & الشبه & \\
\hline 30.11 & 50.2 & 97.12 & 161 & 95.99 & 150.48 & 85.48 & 88 & 1 \\
\hline 32.15 & 51.21 & 98.8 & 202.41 & 98.55 & 156.23 & 92.98 & 163.6 & $\xi$ \\
\hline 29.23 & 55.54 & 84.22 & 207 & 84.85 & 166.7 & 64.97 & 166.46 & v \\
\hline
\end{tabular}

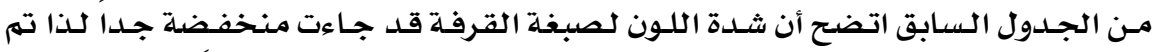

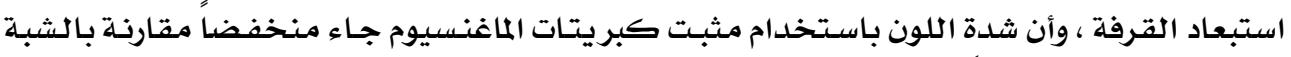

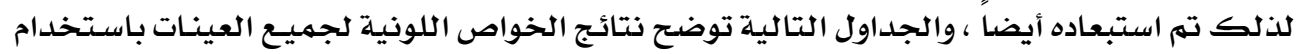

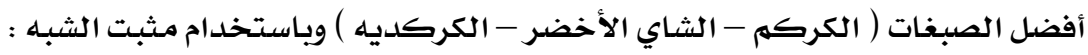


مجلة بحوث التربية النوعية - علد بr - أبريل 10 r ب ب

جدول (ع ) يوضح نتائج اختبار ثبات اللون للاحتكاك (جاف - رطب) (الدرجة من ه)

\begin{tabular}{|c|c|c|c|c|c|c|}
\hline \multicolumn{2}{|c|}{ الشاي الأخضر } & \multicolumn{2}{|c|}{ الكركديه } & \multicolumn{2}{|c|}{ الكركم } & \multirow[t]{2}{*}{ العينة } \\
\hline رطب & جاف & رطب & جاف & رطب & جاف & \\
\hline 3 & 4 & 3.5 & 4 & 3 & 4 & 1 \\
\hline 3 & 4 & 3.5 & 4 & 2.5 & 3.5 & $r$ \\
\hline 3 & 4 & 3.5 & 4 & 2.5 & 4 & $r$ \\
\hline 3 & 3.5 & 3.5 & 4 & 2.5 & 3.5 & $\varepsilon$ \\
\hline 2.5 & 3.5 & 3 & 3.5 & 3 & 3.5 & 0 \\
\hline 3 & 4 & 3 & 3.5 & 2.5 & 3.5 & 7 \\
\hline 3.5 & 4 & 3.5 & 4 & 2.5 & 3.5 & $\checkmark$ \\
\hline 3 & 4 & 3.5 & 4 & 2.5 & 3.5 & $\Lambda$ \\
\hline 3 & 4 & 3 & 4 & 3 & 4 & 9 \\
\hline
\end{tabular}

جدول (ه) يوضح نتائج اختبار ثبات اللون للعرق (حمضي - قلوي) (الدرجة من ه)

\begin{tabular}{|c|c|c|c|c|c|c|c|c|c|c|c|c|}
\hline \multicolumn{4}{|c|}{ الشاي الأخضر } & \multicolumn{4}{|c|}{ الكركديه } & \multicolumn{4}{|c|}{ الكركم } & \multirow{3}{*}{ الصعا العرة } \\
\hline \multicolumn{2}{|c|}{ قلوى } & \multicolumn{2}{|c|}{ حضضى } & \multicolumn{2}{|c|}{ قلوى } & \multicolumn{2}{|c|}{ حضى } & \multicolumn{2}{|c|}{ قلوى } & \multicolumn{2}{|c|}{ حضي } & \\
\hline نضوح & القلوي & الحضضي & لحهضي & القلوي & القلوي | & الحضوح & الحضي & نضوح & القلوي & الحضوح & الحمضي & \\
\hline 4 & 4 & 4 & 4 & 4 & 4 & 4 & 3.5 & 3 & 3 & 3 & 3 & 1 \\
\hline 4 & 4 & 4 & 4 & 4 & 4 & 4 & 3.5 & 3 & 3 & 3 & 3 & $r$ \\
\hline 4 & 4 & 4 & 4 & 4 & 4 & 4 & 3.5 & 3 & 3 & 3 & 3 & $r$ \\
\hline 4 & 4 & 4 & 4 & 4 & 4 & 4 & 3.5 & 3.5 & 3.5 & 4 & 4 & $\xi$ \\
\hline 4 & 4 & 4 & 4 & 4 & 4 & 4 & 3.5 & 3.5 & 3.5 & 4 & 4 & 0 \\
\hline 4 & 4 & 4 & 4 & 4 & 4 & 4 & 3.5 & 4 & 4 & 4 & 4 & 1 \\
\hline 4 & 4 & 4 & 4 & 4 & 4 & 4 & 3.5 & 4 & 4 & 4 & 4 & v \\
\hline 4 & 4 & 4 & 4 & 4 & 4 & 4 & 3.5 & 4 & 4 & 4 & 4 & $\wedge$ \\
\hline 4 & 4 & 4 & 4 & 4 & 4 & 4 & 3.5 & 4 & 4 & 4 & 4 & 9 \\
\hline
\end{tabular}


جدول (ج) يوضح نتائج اختبار ثبات اللون للغسيل(عينة الغسيل - نضوح الغسيل) ( الدرجة من ه)

\begin{tabular}{|c|c|c|c|c|c|c|}
\hline \multicolumn{2}{|c|}{ الشاي الأخضر } & \multicolumn{2}{|c|}{ الكركلديه } & \multicolumn{2}{|c|}{ الكركم } & \multirow[b]{2}{*}{ لعينة } \\
\hline الفسيل & الفيسيل & الفضوح & الفينة & نضوح & عينة الفسيل & \\
\hline 4 & 3.5 & 2.5 & 3 & 2 & 2 & 1 \\
\hline 4 & 3.5 & 2.5 & 3 & 2 & 2 & $r$ \\
\hline 4 & 4 & 2.5 & 3 & 2.5 & 2.5 & $r$ \\
\hline 3.5 & 3 & 3 & 3.5 & 2.5 & 2.5 & $\varepsilon$ \\
\hline 4 & 3.5 & 3 & 3.5 & 2 & 2 & 0 \\
\hline 4 & 4 & 3 & 3.5 & 2.5 & 2.5 & 9 \\
\hline 4 & 4 & 3.5 & 4 & 3 & 3 & $r$ \\
\hline 4 & 4 & 3.5 & 4 & 3 & 3 & $\wedge$ \\
\hline 4 & 4 & 3.5 & 4 & 3 & 3 & 9 \\
\hline
\end{tabular}

جدول (v) يوضح نتائج اختبار ثبات اللون للضوء (الدرجة من ^)

\begin{tabular}{|c|c|c|c|}
\hline الشاى الاخضر & الكركديه & الكركم & الصبفة \\
\hline 7 & 6.5 & 6 & 1 \\
\hline 7 & 7 & 6 & $r$ \\
\hline 7 & 7 & 5 & $r$ \\
\hline 7 & 7 & 6 & $\varepsilon$ \\
\hline 7 & 7 & 6 & 0 \\
\hline 7 & 7 & 6 & 7 \\
\hline 7 & 6.5 & 6 & $r$ \\
\hline 7 & 6.5 & 6 & $\wedge$ \\
\hline 7 & 6.5 & 5 & 9 \\
\hline
\end{tabular}




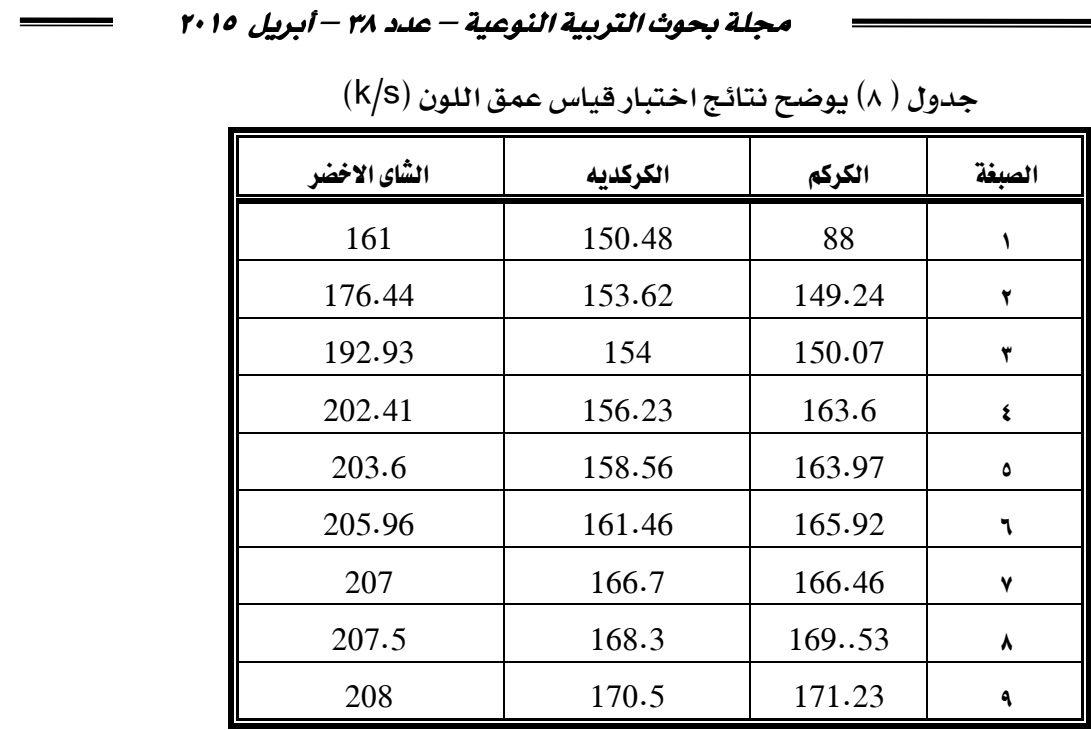

الفرض الأول :

توجد علاقة ذات دلالة إحصائية بـين نوع كل مـن ( الصبغة - المثبـ) والتأثير علي عمق اللون لأقمشة السنسجل جرسيـا

تم توضيح ذلك الفـرض باستخدام نتائج عمق اللون لصبغات ( الكركم - الكركديـه - الكرفئ

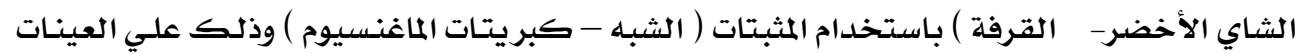

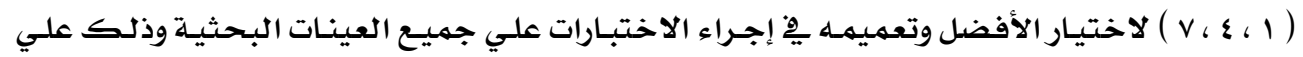
النحو التالي: جدول (ه) يوضح تحليل التباين الأحادي هِ اتجاهين (Two- Way ANOVA) لتأثير الصبغة والمثبت علي

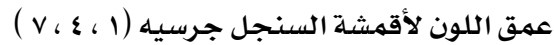

\begin{tabular}{|c|c|c|c|c|c|}
\hline مستوي المعنوية & قيمة اللهفالله & متوسط المربعات & درجات الحرية & مجموع المربعات & مصدر التباين \\
\hline .000 & 21.544 & 11682.806 & 3 & 35048.418 & الصبغات \\
\hline \multirow[t]{2}{*}{.000} & 40.318 & 21863.599 & 1 & 21863.599 & المثبتات \\
\hline & & 542.285 & 19 & 10303.417 & الخطاً \\
\hline & & & 23 & 67215.434 & المجموع \\
\hline
\end{tabular}

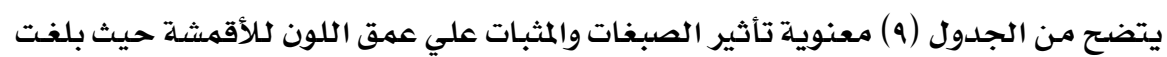

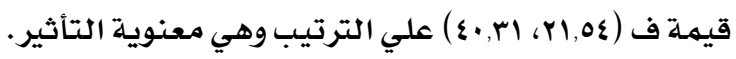




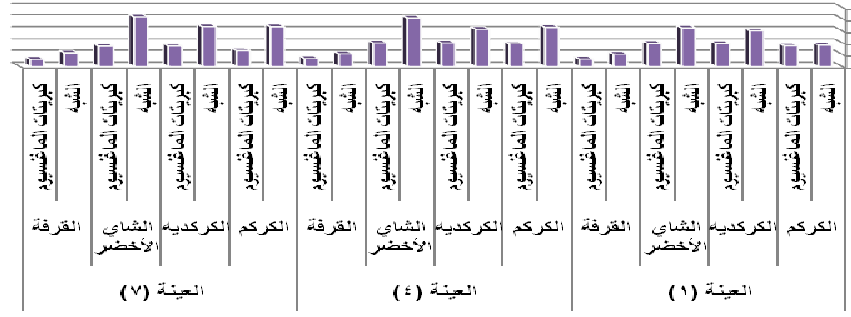

شكل (1) يوضح المتوسطات لتأثير كل من الصبغة والمثبت علي عمق اللون للعينات (1، ع، V) ولتحديد اتجاه الفروق بين الصبغات المختلفة تم تطبيق اختبار Tukey للهقارنات المتعسددة وذلك علي النحو التالي :

جدول ( ـ 1) يوضح الفروق بين المتوسطات للمقارنات المتعددة بين الصبغات ِِّ التأثير علي عمق اللون

\begin{tabular}{|c|c|c|c|c|}
\hline 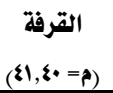 & 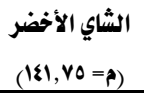 & 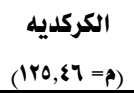 & 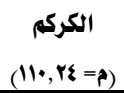 & \\
\hline$* \eta \Lambda, \wedge \varepsilon$ & $r 1,01$ & $10, r 1$ & & الكركم \\
\hline$*_{\wedge \varepsilon, \bullet \uparrow}$ & 17,79 & & & الكركديه \\
\hline \multirow[t]{2}{*}{$* 1 . .$, ro } & & & & الشاي الأخضر \\
\hline & & & & القرفة \\
\hline
\end{tabular}

حيث أن : * فرق معنوي عند مستوي (ه ., •) ، م متوسط النتائج .

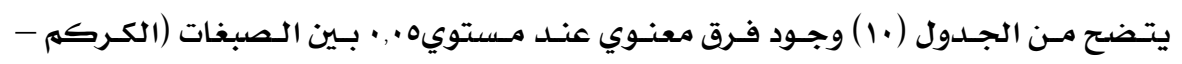

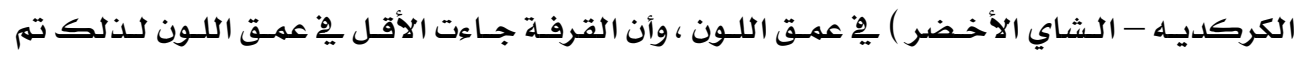

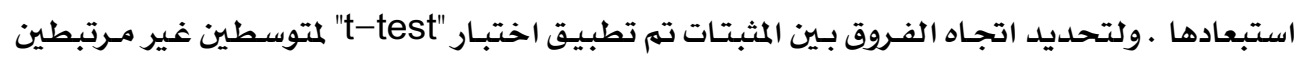

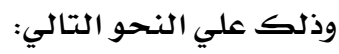

جدول (11) يوضح الفروق بين المتوسطات للمقارنات المتعددة بين المثبتات هِ التأثير علي عمق اللون

\begin{tabular}{|c|c|c|c|c|c|}
\hline مستوي الدلالة & قيمة "ت" & درجة الحرية & الانحراف المعياري & التتوسط & الثبت \\
\hline \multirow{2}{*}{ دالة عند مستوي ••, } & \multirow{2}{*}{3.25} & \multirow{2}{*}{22} & 57.71530 & 134.9025 & (الشبه) \\
\hline & & & 28.13962 & 74.5375 & (كبريتات الماغنسيوم) \\
\hline
\end{tabular}

يتبين من نتائج الجدول (11) أن هناك فروق دالة إحصائياً عند مستوي ه •. • بين نوعي المثبت

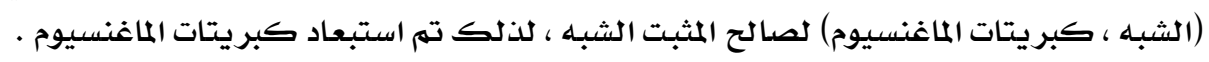
الفرض الثاني : الشبه ، توبتات

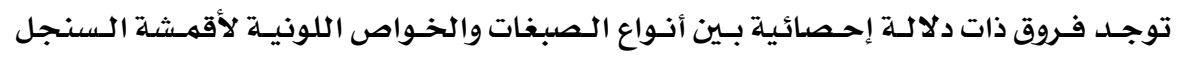


جدول (r ) يوضح تحليل التباين لتأثير نوع الصبغة ( الكركم - الكركديه - الشاي الأخضر) وباستخدام

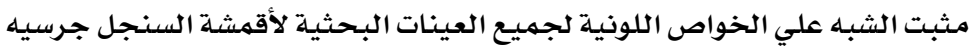

\begin{tabular}{|c|c|c|c|c|c|}
\hline الدلالة & قيمة (ف) & متوسط المربعات & د ل درجات العرية & مجموع المربعات & مصلدر التباين \\
\hline \multicolumn{6}{|c|}{ أولا: عمق اللون } \\
\hline \multirow[t]{3}{*}{ 0., دار } & 13.832 & 4635.151 & 2 & 9270.302 & بين المجموعات \\
\hline & & 335.109 & 24 & 8042.622 & داخل المجموعات \\
\hline & & & 26 & 17312.924 & المجموع \\
\hline \multicolumn{6}{|c|}{ ثانياً : ثبات اللون للفسيل (عينة الفسيل) } \\
\hline \multirow[t]{3}{*}{ 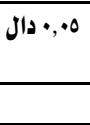 } & 22.575 & 3.815 & 2 & 7.630 & بين المجموعات \\
\hline & & .169 & 24 & 4.056 & داخل المجموعات \\
\hline & & & 26 & 11.685 & المجهوع \\
\hline \multicolumn{6}{|c|}{ ل ثبات اللون للفسيل (نضوح الفسيل) } \\
\hline \multirow[t]{3}{*}{ 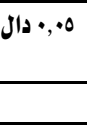 } & 36.069 & 4.843 & 2 & 9.685 & بين المجموعات \\
\hline & & .134 & 24 & 3.222 & داخل المجموعات \\
\hline & & & 26 & 12.907 & التباين الكلي \\
\hline \multicolumn{6}{|c|}{ ل ثالثًا : ثبات اللوز للضوى } \\
\hline \multirow[t]{3}{*}{ 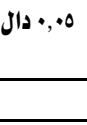 } & & 3.815 & 2 & 7.630 & بين المجموعات \\
\hline & 43.368 & .088 & 24 & 2.111 & داخل المجموعات \\
\hline & & & 26 & 9.741 & التباين الكلي \\
\hline \multicolumn{6}{|c|}{ رابعاً : ثبات اللون للاحتكاك (جاف) } \\
\hline \multirow[t]{3}{*}{ 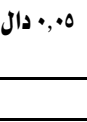 } & & .148 & 2 & .296 & بين المجموعات \\
\hline & 2.783 & .053 & 24 & 1.278 & داخل المجموعات \\
\hline & & & 26 & 1.574 & التباين الكلي \\
\hline \multicolumn{6}{|c|}{ ل ثبات اللون للاحتكاك (رطب) } \\
\hline \multirow[t]{3}{*}{ 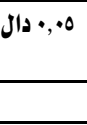 } & & 1.000 & 2 & 2.000 & بيز المجموعات \\
\hline & 16.000 & .063 & 24 & 1.500 & داخل المجموعات \\
\hline & & & 26 & 3.500 & التباين الكلي \\
\hline \multicolumn{6}{|c|}{ خامساً: : ثبات اللون للعرق الحامضي (عينة الحامضي) } \\
\hline \multirow[t]{3}{*}{ 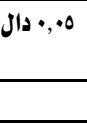 } & & .583 & 2 & 1.167 & بين المجموعات \\
\hline & 7.000 & .083 & 24 & 2.000 & داخل المجموعات \\
\hline & & & 26 & 3.167 & التباين الكلي \\
\hline \multicolumn{6}{|c|}{ ثبات اللون للعرق الحامضي (نضوح الحامضي) } \\
\hline \multirow[t]{3}{*}{ 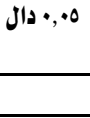 } & & .333 & 2 & .667 & بين المجموعات \\
\hline & 4.000 & .083 & 24 & 2.000 & داخل المجموعات \\
\hline & & & 26 & 2.667 & التباين الكلي \\
\hline \multicolumn{6}{|c|}{ لثبات اللون للعرق القلوي (عينة القلوي) } \\
\hline \multirow[t]{3}{*}{ ه.,• دال } & & .593 & 2 & 1.185 & بين المجموعات \\
\hline & 8.258 & .072 & 24 & 1.722 & داخل المجموعات \\
\hline & & & 26 & 2.907 & التباين الكلي \\
\hline \multicolumn{6}{|c|}{ لثبات اللون للعرق القلوي (نضوح القلوي) } \\
\hline \multirow[t]{3}{*}{ ••,• دال } & 8.258 & .593 & 2 & 1.185 & بين المجموعات \\
\hline & & .072 & 24 & 1.722 & داخل المجموعات \\
\hline & & & 26 & 2.907 & التباين الكلي \\
\hline
\end{tabular}




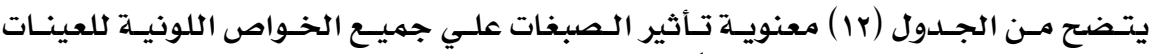

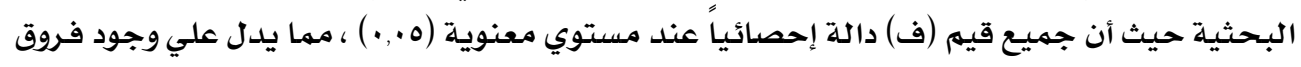

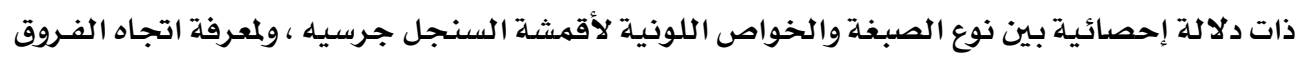

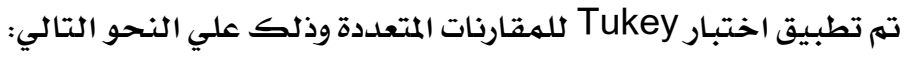
أولاً : عمق اللون : تصليق اختبار

جدول (r) يوضح الفروق بين المتوسطات للمقارنات المتعددة لتأثير نوع الصبغة علي عمق اللون

لأقمشة السنجل جرسيـ

\begin{tabular}{|c|c|c|c|}
\hline الشاي الأخضر (م= 9•,197) & الكركلديه (م= 109,91) & الكركم (P = (10\&, & \\
\hline$*_{21, \wedge \uparrow}$ & $\frac{*}{x}$, Yo & & الكركم \\
\hline \multirow[t]{2}{*}{$* r q, 11$} & & & الكركديه \\
\hline & & & الشاي الأخضر \\
\hline
\end{tabular}

يتضح من الجدول (r) ) أن العينات المصبوغة باستخدام صبغة الشاي الأخضر أعطت أعلي

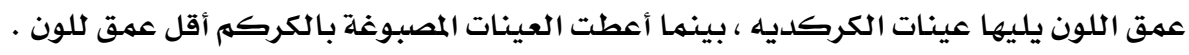

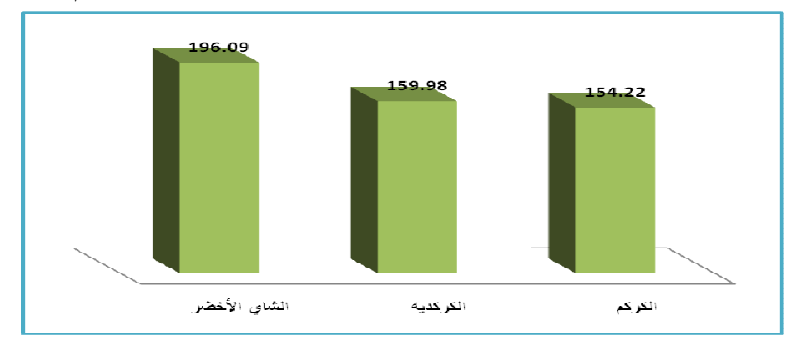

شكل (r) يوضـح متوسطات الصبغات يِّ تأثيرها علي قياس عمق اللون

ثانياً : ثبات اللون للغسيل

جدول (ع ا ) يوضح الفروق بين المتوسطات للمقارنات المتعددة لتأثير نوع الصبغة علي ثبات اللون للغسيل

\begin{tabular}{|c|c|c|c|c|}
\hline \multicolumn{5}{|c|}{ لأقمشة السنـجل جرسيـ } \\
\hline الشاي الأخضر (P=Pr,Vr) & الكركديه (م= •., ب) & الكركم (P= • (Y,0) & & ثبات اللون للفسيل \\
\hline$*_{1, r r}$ & $*_{1}, \cdot \cdot$ & & الكركم الكم & \multirow{3}{*}{ عينة الفسيل } \\
\hline \multirow[t]{2}{*}{$\cdot, r r$} & & & الكركديه & \\
\hline & & & الشاي الأخضر & \\
\hline 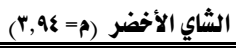 & الكركديه (م= •,", ) & الكركم (p= •.0, & & \\
\hline$*_{1, \text { }\{\varepsilon}$ & $*_{,}, 0$. & & الكركم & \multirow{3}{*}{ نضوح الفسيل } \\
\hline 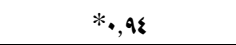 & & & الكركلديه & \\
\hline & & & الشاي الأخضر & \\
\hline
\end{tabular}


يتضح من الجدول (\& 1) أن العينات المصبوغة باستخدام صبغة الشاي الأخضر أعطت أعلي

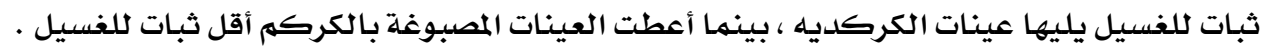

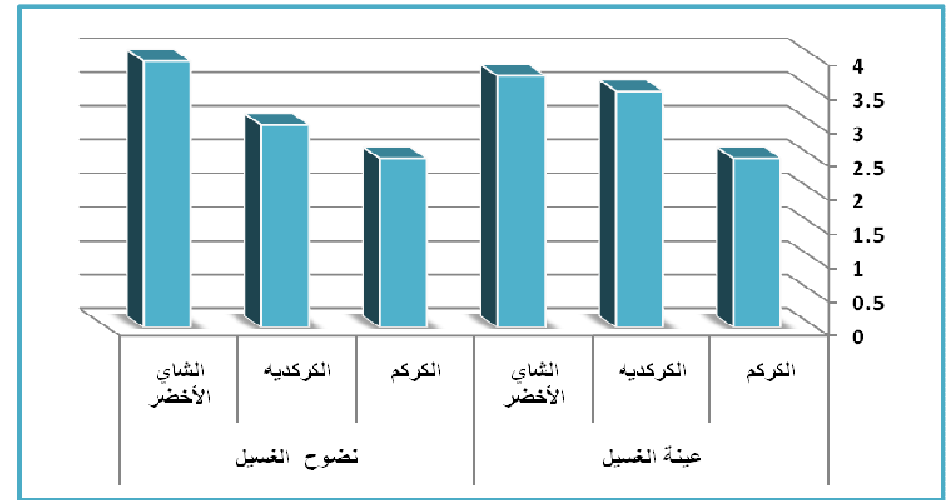

شكل (r) يوضح متوسطات الصبغات بِّ تأثيرها علي ثبات اللون للغسيل (عينة الغسيل - نضوح الغسيل)

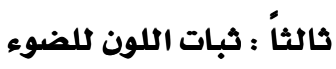

جدول (10) يوضح الفروق بين المتوسطات للمقارنات المتعددة لتأثير نوع الصبغة علي ثبات اللون للضوء

لأقمشة السنجل جرسيه

\begin{tabular}{|c|c|c|c|}
\hline الشاي الأخضر & $\begin{array}{l}\text { الكركلديه } \\
(1, Y \Lambda=P(P)\end{array}$ & $\begin{array}{c}\text { الكركم } \\
(0, Y A=P)\end{array}$ & \\
\hline$*_{1, r r}$ & $*_{1}, \cdot \cdot$ & & الكركم \\
\hline \multirow[t]{2}{*}{ • } & & & الكركلديه \\
\hline & & & الشاي الأخضر \\
\hline
\end{tabular}

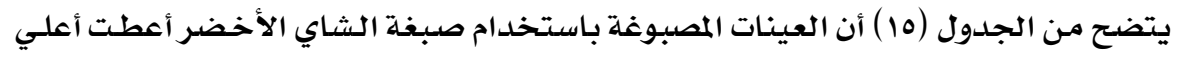

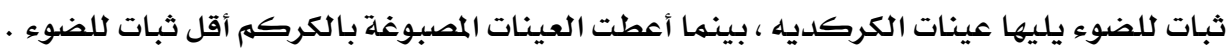

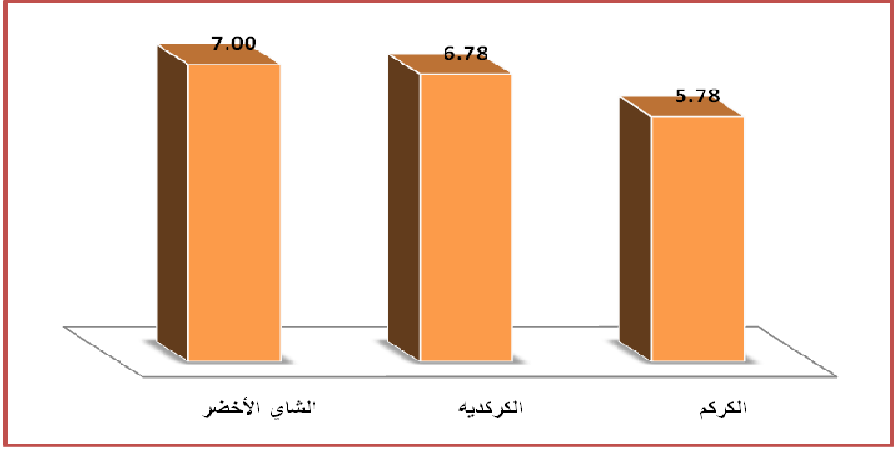

شكل ( ) يوضح متوسطات الصبغات يِّ تأثيرها علي ثبات اللون للضوء 


\section{دراسة جودة الخواص اللونية لبعض الصبغات الطبيعية على اقمشة (السنجل جرسيه) \\ رابعاً: ثبات اللون للاحتكاك ( جاف - رطب)}

جدول (1 ) يوضح الفروق بين المتوسطات للمقارنات المتعددة لتأثير نوع الصبغة علي ثبات اللون للاحتكاك

\begin{tabular}{|c|c|c|c|c|}
\hline 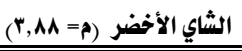 & الكركلديه (ק= = (广, ) & الكركم (ק= $77, \%$ & & ثبات اللون للاحتكاك \\
\hline$*_{,}, r r$ & $*_{\cdot, r r}$ & & الكركم & \multirow{3}{*}{ جاف اف } \\
\hline \multirow[t]{2}{*}{$\cdot, \cdot \cdot$} & & & الكركديه & \\
\hline & & & الشاي الأخضر & \\
\hline الشاي الأخضر (P= •,", ) & الكركديه (P= = (T, & الكركم (ק= = 17, & & \\
\hline$*_{,}, r r$ & $*_{\cdot, 77}$ & & الكركم & \multirow{3}{*}{ رطب } \\
\hline$*_{,}, r r$ & & & الكركديه & \\
\hline & & & الشاي الأخضر & \\
\hline
\end{tabular}

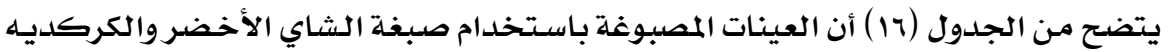

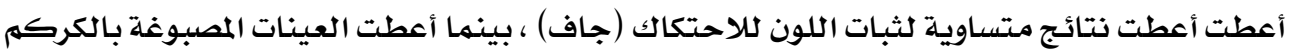

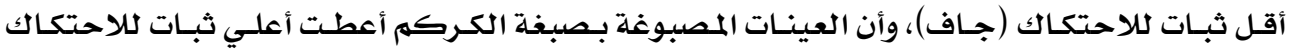

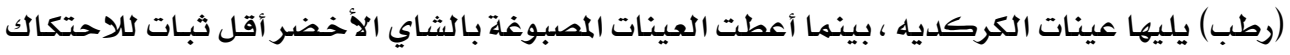
. (رطب)

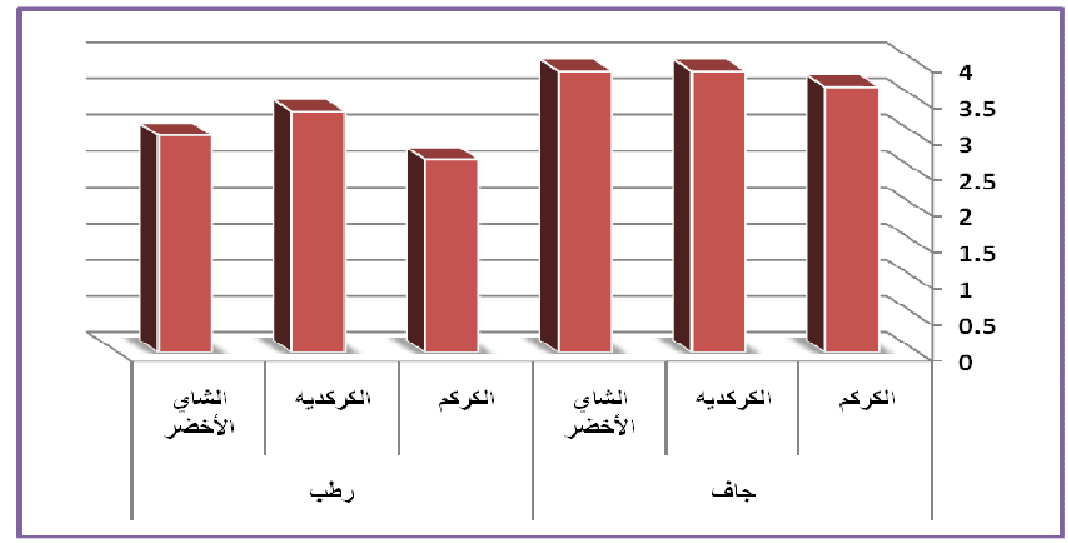

شكل (ه) يوضح متوسطات الصبغات هِّ تأثيرها علي ثبات اللون للاحتكاك (جاف - رطب) 
خامساً: ثبات اللون للعرق( حامضي - قلوي) جدول (IV) يوضح الفروق بين المتوسطات للمقارنات المتعددة لتأثير نوع الصبغة علي ثبات اللون للعرق

\begin{tabular}{|c|c|c|c|c|}
\hline 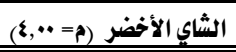 & الكركديه (م= •0, بر) & 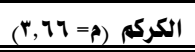 & & ثبات اللوز للعرق \\
\hline$*_{\bullet, r r}$ & $*_{., 17}$ & & الكركم & \multirow{3}{*}{ حضي (الحمضي) } \\
\hline \multirow[t]{2}{*}{$*_{\cdot, 0}$} & & & الكركلديه & \\
\hline & & & الشاي الأخضر & \\
\hline الشاي الأخضر (م="•,؛) & الكركلديه (ק= •,, (צ) & 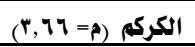 & & \\
\hline$*$, rr & $*_{\bullet, r r}$ & & الكركم & \multirow{3}{*}{ عضي (نضوح الحمضي) | } \\
\hline \multirow[t]{2}{*}{$\cdot, \cdot \bullet$} & & & الكركديه & \\
\hline & & & الشاي الأخضر & \\
\hline الشاي الأخضر (\$= •, (צ) & الكركديه (م= ", (צ) & الكركم (م= = r,ه0) & & \\
\hline 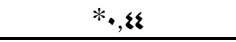 & $*_{\bullet, \text { Iq }}$ & & الكركم & \multirow{3}{*}{ قلوي (القلوي) } \\
\hline \multirow[t]{2}{*}{$\cdot, \cdot \cdot$} & & & الكركديه & \\
\hline & & & الشاي الأخضر & \\
\hline الشاي الأخضر (\$= •,,\&) & 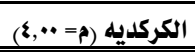 & الكركم (م= = r, r) & & \\
\hline$*$, \& & $*_{,, \text {I }}$ & & الكركم & \multirow{3}{*}{ قلوي (نضوح القلوي) } \\
\hline \multirow[t]{2}{*}{$\cdot, \cdot$} & & & الكركديه & \\
\hline & & & الشاي الأخضر & \\
\hline
\end{tabular}

يتضح من الجدول (IV) أن العينات المصبوغة باستخدام صبغة الشاي الأخضر أعطت أعلسي

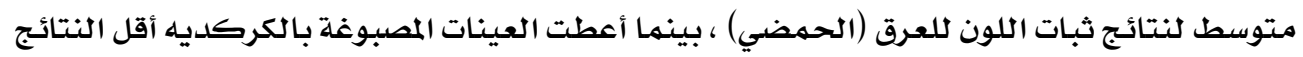

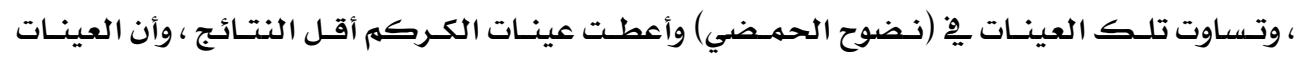

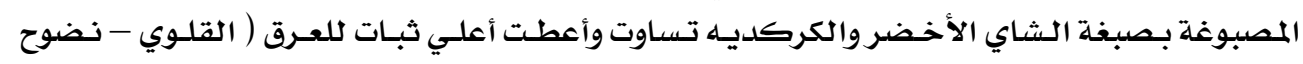

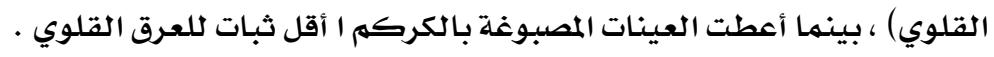

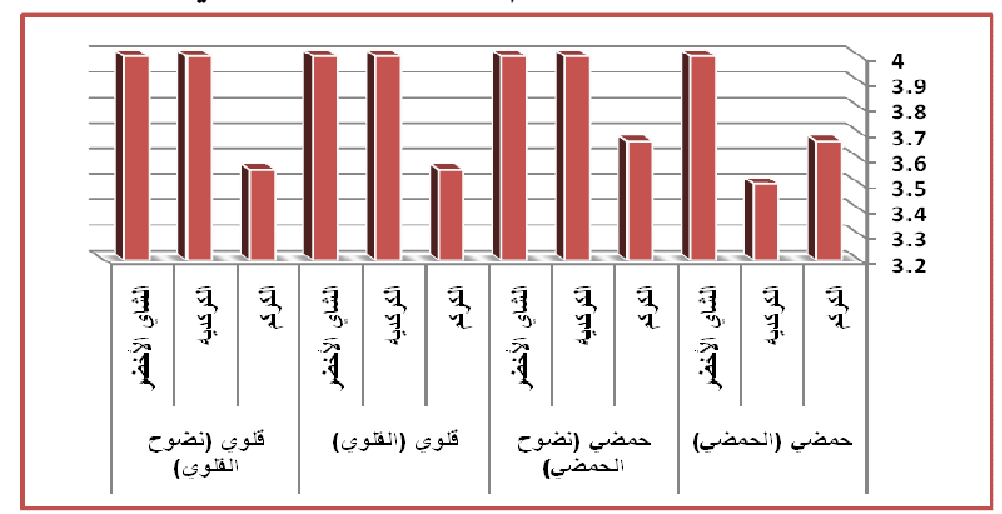

شكل (ج) يوضح متوسطات الصبغات يِّ تأثيرها علي ثبات اللون للعرق (حمضي - قلوي) 
توجـد علاقـة ذات دلالـة احسـائية بـين التركيـب البنـائي لأقمشـة السنـجل جرسـيه وجـودة

$$
\text { الخواص اللونية للصبغات الطبيعية }
$$

جدول (1) يوضح تقييم الجودة الكلية لتأثير التركيب البنائي لأقمشة السنجل جرسيه علي الخواص اللونية باستخدام صبغة الكركم الطبيعية

\begin{tabular}{|c|c|c|c|c|c|c|c|c|c|c|c|c|c|c|c|}
\hline \multirow{3}{*}{ الجودة } & \multirow{3}{*}{ المثالية } & \multirow{2}{*}{\multicolumn{2}{|c|}{ ثلاحتكاك اللون }} & \multicolumn{4}{|c|}{ ثبات اللون للعرق } & \multirow{2}{*}{\multicolumn{2}{|c|}{ ثلفبات اللون }} & \multirow{3}{*}{ اللبات } & \multirow{3}{*}{ عمق اللون } & \multirow{3}{*}{ الفرزه } & \multirow{3}{*}{ الوز (جم) } & \multirow{3}{*}{ نمرة } & \multirow{3}{*}{ رقينة } \\
\hline & & & & \multicolumn{2}{|c|}{ قلوى } & \multicolumn{2}{|c|}{ حهضي } & & & & & & & & \\
\hline & & رطب & جاف & | التقوي & القلوي & الحمضب & الحمضي & الفسيل & الغسيلة & & & & & & \\
\hline 58.64 & 586.39 & 60 & 80 & 60 & 60 & 60 & 60 & 40 & 40 & 75 & 51.39 & 2.7 & 85 & $1 / 30$ & 1 \\
\hline 60.22 & 602.16 & 50 & 70 & 60 & 60 & 60 & 60 & 40 & 40 & 75 & 87.16 & 1.8 & 93 & $1 / 30$ & 2 \\
\hline 62.01 & 620.14 & 50 & 80 & 60 & 60 & 60 & 60 & 50 & 50 & 62.5 & 87.64 & 1.3 & 116 & $1 / 30$ & 3 \\
\hline 69.05 & 690.54 & 50 & 70 & 70 & 70 & 80 & 80 & 50 & 50 & 75 & 95.54 & 2.7 & 113 & $1 / 24$ & 4 \\
\hline 68.08 & 680.76 & 60 & 70 & 70 & 70 & 80 & 80 & 40 & 40 & 75 & 95.76 & 1.8 & 140 & $1 / 24$ & 5 \\
\hline 71.19 & 711.90 & 50 & 70 & 80 & 80 & 80 & 80 & 50 & 50 & 75 & 96.90 & 1.3 & 168 & $1 / 24$ & 6 \\
\hline 73.22 & 732.21 & 50 & 70 & 80 & 80 & 80 & 80 & 60 & 60 & 75 & 97.21 & 2.7 & 148 & $1 / 20$ & 7 \\
\hline 73.40 & 734.01 & 50 & 70 & 80 & 80 & 80 & 80 & 60 & 60 & 75 & 99.01 & 1.8 & 178 & $1 / 20$ & 8 \\
\hline 74.25 & 742.50 & 60 & 80 & 80 & 80 & 80 & 80 & 60 & 60 & 62.5 & 100.00 & 1.3 & 200 & $1 / 20$ & 9 \\
\hline
\end{tabular}

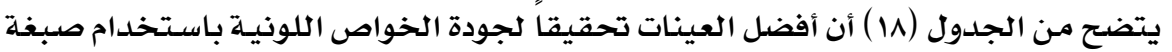

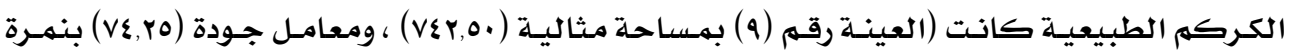

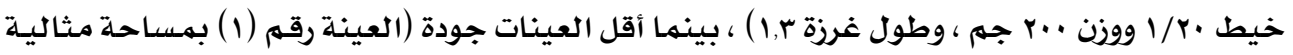

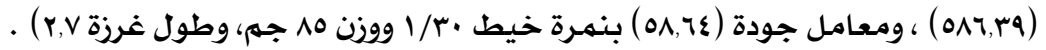

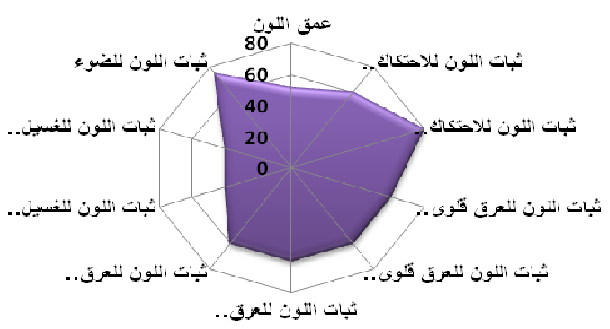

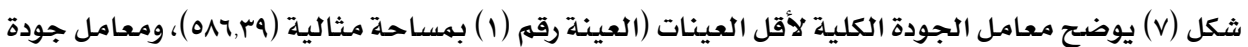

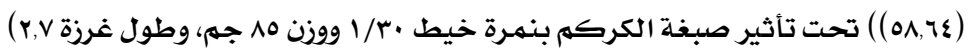




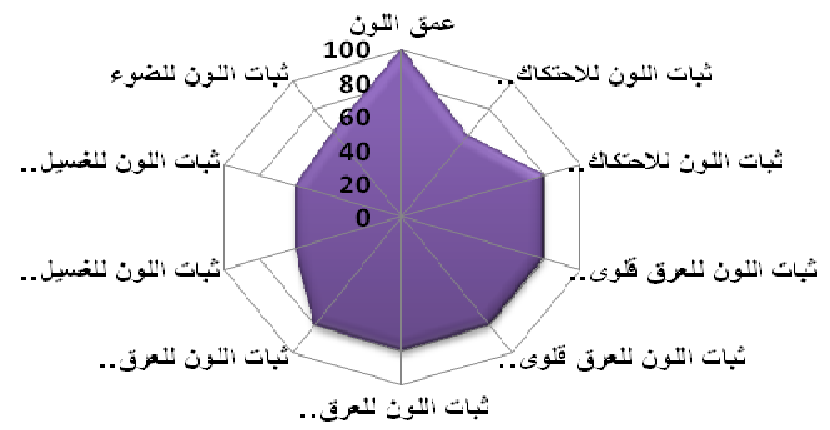

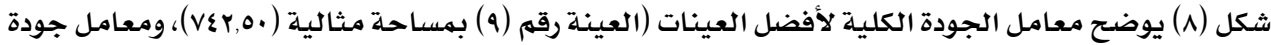

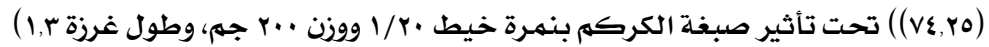

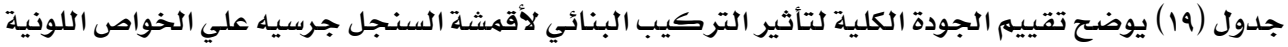
ساستخدام صبغة الكركلديه الطبيعية

\begin{tabular}{|c|c|c|c|c|c|c|c|c|c|c|c|c|c|c|c|}
\hline \multirow{3}{*}{ الجودة } & \multirow{3}{*}{ المثالية } & \multirow{2}{*}{\multicolumn{2}{|c|}{ ثلاحتكات اللون }} & \multicolumn{4}{|c|}{ ثبات اللون للعرق } & \multirow{2}{*}{\multicolumn{2}{|c|}{ ثبات اللون }} & \multirow{3}{*}{ |للبود اللون } & \multirow{3}{*}{ عمق اللوز } & \multirow{3}{*}{ الفرزه } & \multirow{3}{*}{ |الوزن) } & \multirow{3}{*}{ الخيط } & \multirow{3}{*}{ رقم } \\
\hline & & & & \multicolumn{2}{|c|}{ قلوى } & \multicolumn{2}{|c|}{ حهضي } & & & & & & & & \\
\hline & & رطب | & جاف & القلوح & القلوي & الحضوح & | الحمضي & | نضوح | الغسيل & الفسيل & & & & & & \\
\hline 73.95 & 739.51 & 70 & 80 & 80 & 80 & 80 & 70 & 50 & 60 & 81.25 & 88.26 & 2.7 & 85 & $1 / 30$ & 1 \\
\hline 74.76 & 747.60 & 70 & 80 & 80 & 80 & 80 & 70 & 50 & 60 & 87.5 & 90.10 & 1.8 & 93 & $1 / 30$ & 2 \\
\hline 74.78 & 747.82 & 70 & 80 & 80 & 80 & 80 & 70 & 50 & 60 & 87.5 & 90.32 & 1.3 & 116 & $1 / 30$ & 3 \\
\hline 76.91 & 769.13 & 70 & 80 & 80 & 80 & 80 & 70 & 60 & 70 & 87.5 & 91.63 & 2.7 & 113 & $1 / 24$ & 4 \\
\hline 75.05 & 750.50 & 60 & 70 & 80 & 80 & 80 & 70 & 60 & 70 & 87.5 & 93.00 & 1.8 & 140 & $1 / 24$ & 5 \\
\hline 75.22 & 752.20 & 60 & 70 & 80 & 80 & 80 & 70 & 60 & 70 & 87.5 & 94.70 & 1.3 & 168 & $1 / 24$ & 6 \\
\hline 78.90 & 789.02 & 70 & 80 & 80 & 80 & 80 & 70 & 70 & 80 & 81.25 & 97.77 & 2.7 & 148 & $1 / 20$ & 7 \\
\hline 79.00 & 789.96 & 70 & 80 & 80 & 80 & 80 & 70 & 70 & 80 & 81.25 & 98.71 & 1.8 & 178 & $1 / 20$ & 8 \\
\hline 78.13 & 781.25 & 60 & 80 & 80 & 80 & 80 & 70 & 70 & 80 & 81.25 & 100.00 & 1.3 & 200 & $1 / 20$ & 9 \\
\hline
\end{tabular}

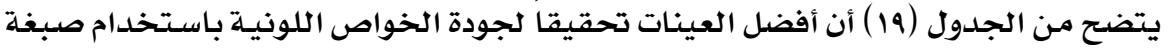

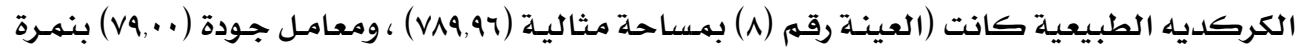

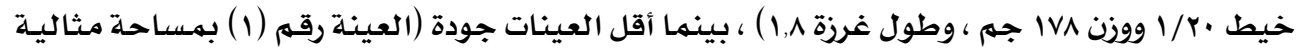

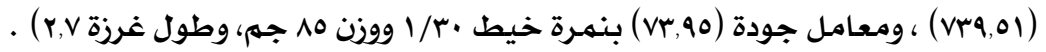




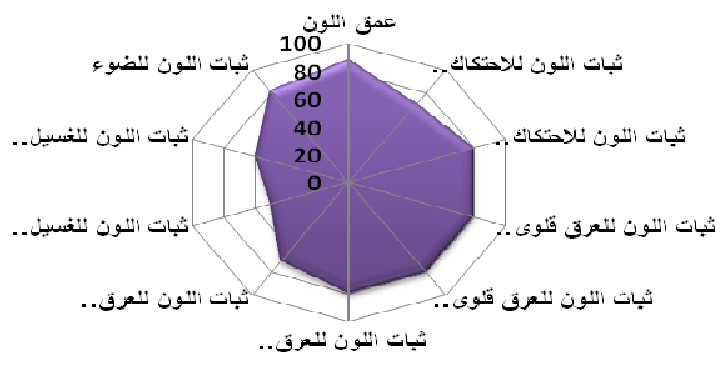

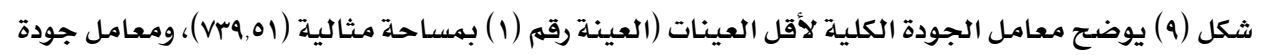

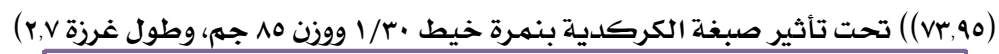

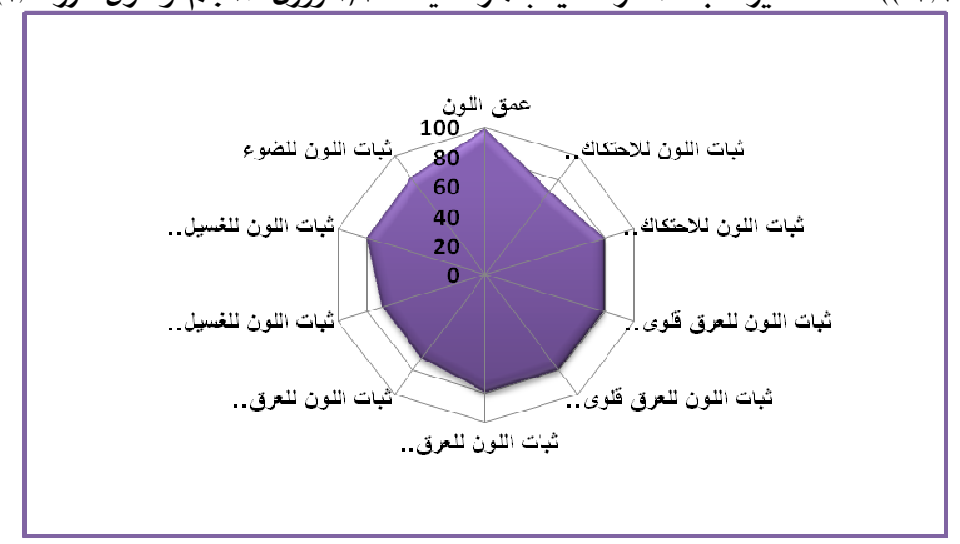

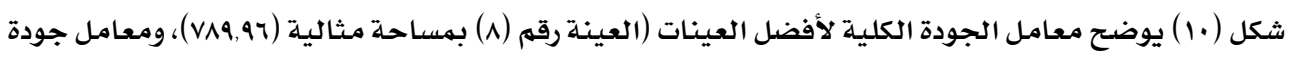

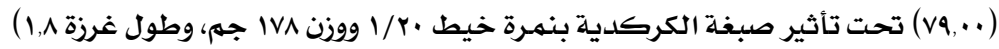


جدول ( • يوضح تقييم الجودة الكلية لتأثير التركيب البنائي لأقمشة السنجل جرسيه علي الخواص اللونية باستخدام صبغة الشاي الأخضر الطبيعية

\begin{tabular}{|c|c|c|c|c|c|c|c|c|c|c|c|c|c|c|c|}
\hline \multirow{3}{*}{ الجودة } & \multirow{3}{*}{ المالية } & \multirow{2}{*}{\multicolumn{2}{|c|}{ ثلاحتكاك اللون }} & \multicolumn{4}{|c|}{ ثبات اللون للعرق } & \multirow{2}{*}{\multicolumn{2}{|c|}{ ثبات اللون }} & \multirow{3}{*}{ لالضوا } & \multirow{3}{*}{ عمق اللون } & \multirow{3}{*}{ الفرزه } & \multirow{3}{*}{ (الوزن } & \multirow{3}{*}{ |الخيط } & \multirow{3}{*}{ رقيم } \\
\hline & & & & \multicolumn{2}{|c|}{ | قلوى } & \multicolumn{2}{|c|}{ حمضي } & & & & & & & & \\
\hline & & رطب & جاف & التلوح & | القلوي & | الحمضوح & الحمضر & الضضوح & | الفسيلة & & & & & & \\
\hline 77.49 & 774.90 & 60 & 80 & 80 & 80 & 80 & 80 & 80 & 70 & 87.5 & 77.40 & 2.7 & 85 & $1 / 30$ & 1 \\
\hline 78.23 & 782.33 & 60 & 80 & 80 & 80 & 80 & 80 & 80 & 70 & 87.5 & 84.83 & 1.8 & 93 & $1 / 30$ & 2 \\
\hline 80.03 & 800.25 & 60 & 80 & 80 & 80 & 80 & 80 & 80 & 80 & 87.5 & 92.75 & 1.3 & 116 & $1 / 30$ & 3 \\
\hline 76.48 & 764.81 & 60 & 70 & 80 & 80 & 80 & 80 & 70 & 60 & 87.5 & 97.31 & 2.7 & 113 & $1 / 24$ & 4 \\
\hline 77.54 & 775.38 & 50 & 70 & 80 & 80 & 80 & 80 & 80 & 70 & 87.5 & 97.88 & 1.8 & 140 & $1 / 24$ & 5 \\
\hline 80.65 & 806.52 & 60 & 80 & 80 & 80 & 80 & 80 & 80 & 80 & 87.5 & 99.02 & 1.3 & 168 & $1 / 24$ & 6 \\
\hline 81.70 & 817.02 & 70 & 80 & 80 & 80 & 80 & 80 & 80 & 80 & 87.5 & 99.52 & 2.7 & 148 & $1 / 20$ & 7 \\
\hline 80.73 & 807.26 & 60 & 80 & 80 & 80 & 80 & 80 & 80 & 80 & 87.5 & 99.76 & 1.8 & 178 & $1 / 20$ & 8 \\
\hline 80.75 & 807.50 & 60 & 80 & 80 & 80 & 80 & 80 & 80 & 80 & 87.5 & 100.00 & 1.3 & 200 & $1 / 20$ & 9 \\
\hline
\end{tabular}

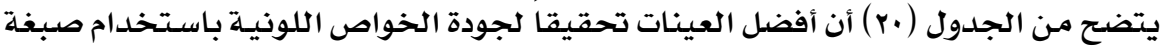

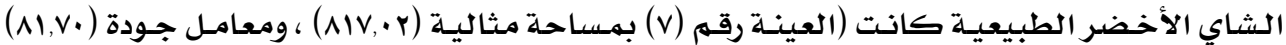

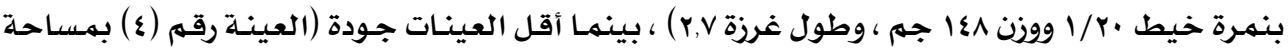

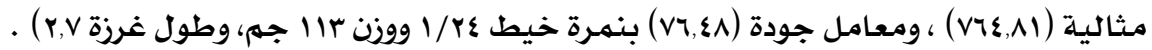

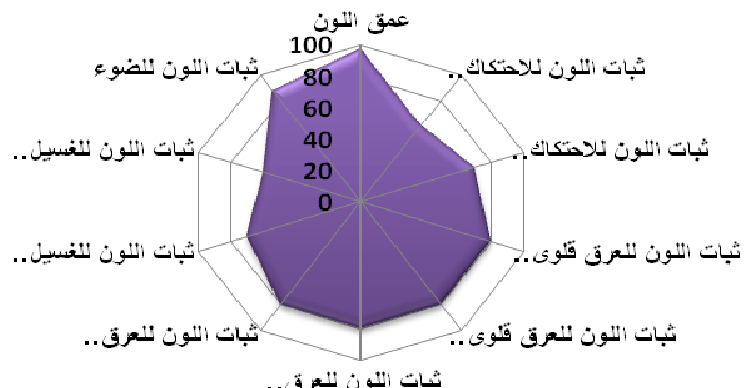

شكل (1) يوضح معامل الجودة الكلية لأقل العينات (العينة رقم (ع) بمساحة مثالية (1) (1) (VT)، ومعامل جودة

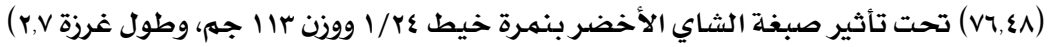




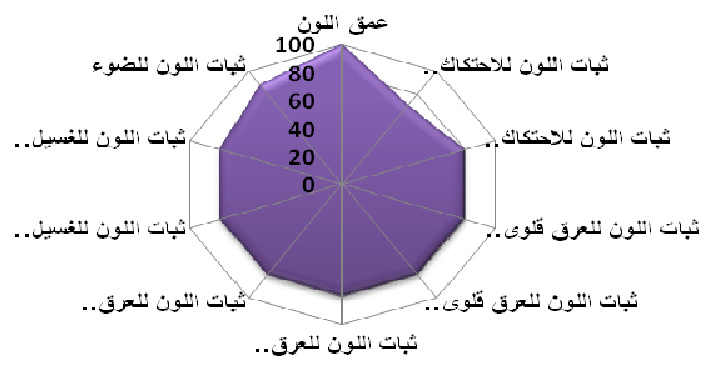

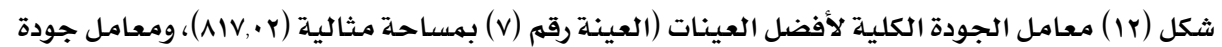

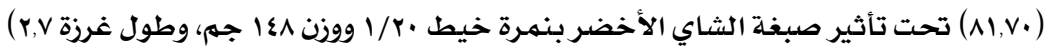
من خلال الجداول السـابقة لتقييم الجودة الكلية يتضـح أن :

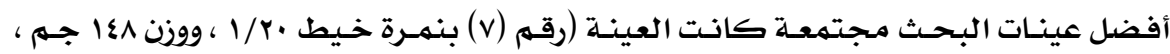

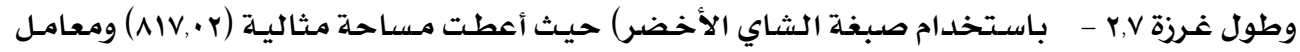

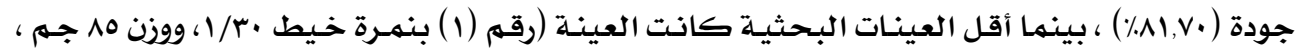

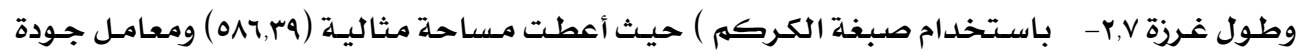
. $(\%$ \% , ๆ $)$

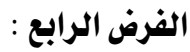

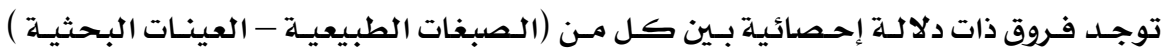
وجودة الخواص اللونية

جدول ( إr) يوضـح تحليل التباين الأحادي يِ اتجاهين (Two- Way ANOVA) للفروق بين (الصبغات العينات) فِ التأثير علي جودة الخواص النونية

\begin{tabular}{|c|c|c|c|c|c|}
\hline مستوي المعنوية & قيعة "ف" & متوسط المربعات & درجات الحرية & مجموع المربعات & مصدر التباين \\
\hline .023 & 3.204 & 26.843 & 8 & 214.747 & العينات \\
\hline \multirow[t]{2}{*}{.000} & 38.279 & 320.701 & 2 & 641.401 & الصبغات \\
\hline & & 8.378 & 16 & 134.046 & الخطأ \\
\hline & & & 26 & 990.194 & المجموع \\
\hline
\end{tabular}

يتضح من الجدول ( ا r) وجود فروق بين متوسطات تقييمات (العينات البحثية - الصبغات

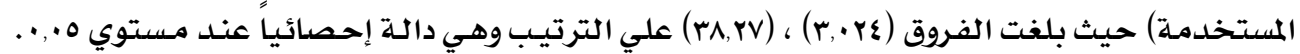

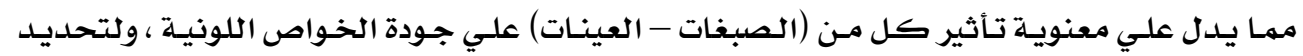




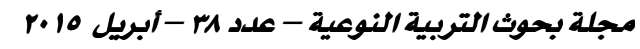

اتجاه الفروق بين كل من الصبغات والعينـات البحثيـة تم تطبيق اختبـار Tukey للمقارنات المتعـددة وذلك علي النحو التالي:

جدول (rr) يوضـح الفروق بين المتوسطات للمقارنات المتعددة لتأثير الصبغات علي جودة الخواص اللونية

\begin{tabular}{|c|c|c|c|}
\hline الشاي الأخضر (P= (va,rq) & الكركديه (م= • VY,r) & الكركم (P = & \\
\hline$* 11.50$ & $* 8.15$ & & الكركم \\
\hline \multirow[t]{2}{*}{2.98} & & & الكركديه \\
\hline & & & الشاي الأخضر \\
\hline
\end{tabular}

يتبين من الجدول(rr ) أن صبغة الشاي الأخضر أعطت أعلي متتوسط لمعامـل الجـودة لعينـات

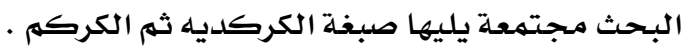

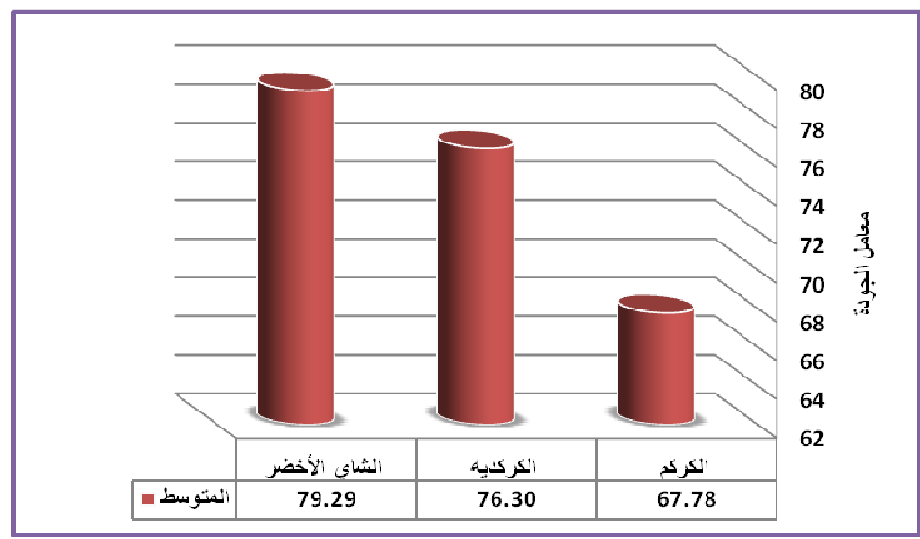

ثكل (r) يوضـح متوسطات معاملات جودة الصبغات علي الخواص اللونية

جدول (rr) يوضح الفروق بين المتوسطات للمقارنات المتعددة لتأثير العينات علي جودة الخواص اللونية

\begin{tabular}{|c|c|c|c|c|c|c|c|c|c|}
\hline $\begin{array}{l}\text { (q) العينة } \\
(v \vee, V I=\text { = })\end{array}$ & $\begin{array}{l}\text { العينة (A) } \\
\text { ( VV, Y = ( ) }\end{array}$ & 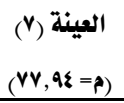 & 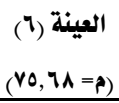 & 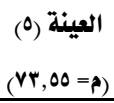 & 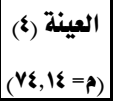 & 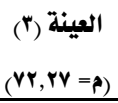 & 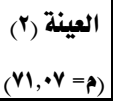 & $\begin{array}{l}\text { العينة (1) } \\
(r \cdot, r=م)\end{array}$ & \\
\hline$* 7.6833$ & *7.6833 & *7.9133 & $5.6600 *$ & 3.5300 & 4.1200 & 2.2467 & 1.0433 & & العينة (1) \\
\hline$* 6.6400$ & $* 6.6400$ & $* 6.8700$ & $* 4.6167$ & 2.4867 & 3.0767 & 1.2033 & & & العينة (r) \\
\hline$* 5.4367$ & $* 5.4367$ & $* 5.6667$ & 3.4133 & 1.2833 & 1.8733 & & & & العينة (r) \\
\hline 3.5633 & 3.5633 & 3.7933 & 1.5400 & .5900 & & & & & العينة (₹) \\
\hline$* 4.1533$ & $* 4.1533$ & $* 4.3833$ & 2.1300 & & & & & & العينة (0) \\
\hline 2.0233 & 2.0233 & 2.2533 & & & & & & & العينة (7) \\
\hline .2300 & .2300 & & & & & & & & العينة (v) \\
\hline .0000 & & & & & & & & & العينة (^) \\
\hline
\end{tabular}




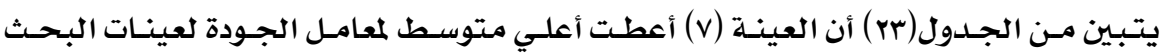

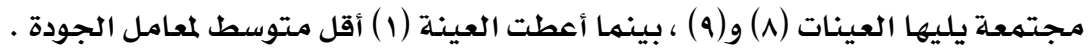

\section{هلخص النتائج :}

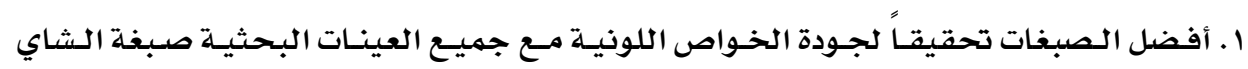

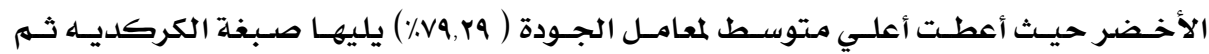

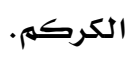

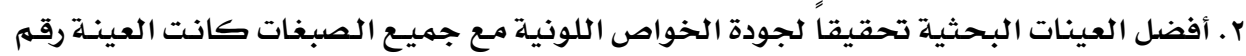

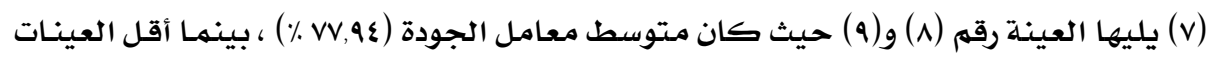

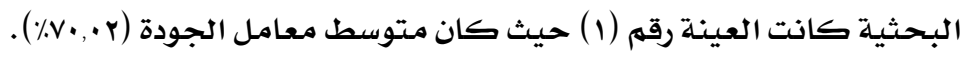

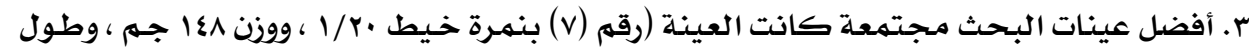

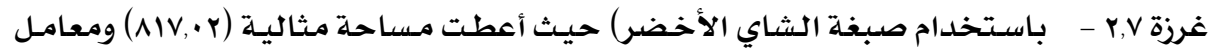

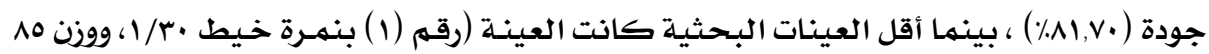

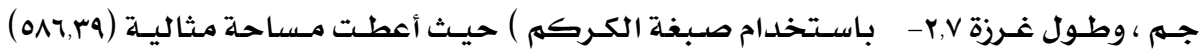

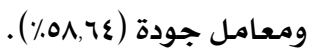

I. تشجيع استخدام الصبغات الطبيعية والعمل علي تطويرها .

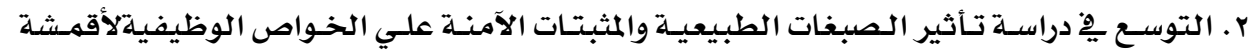

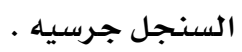

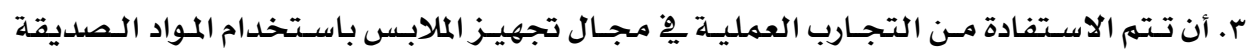

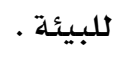

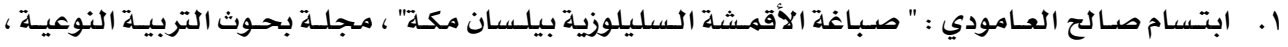

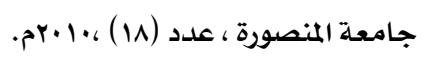

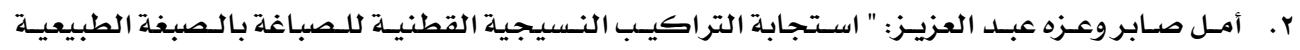

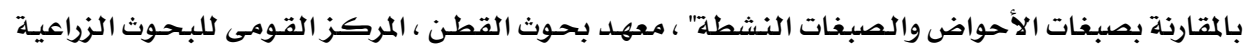

$$
\text { •r.r.r. }
$$

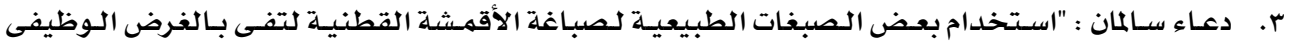

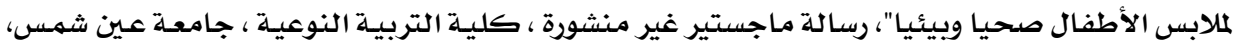

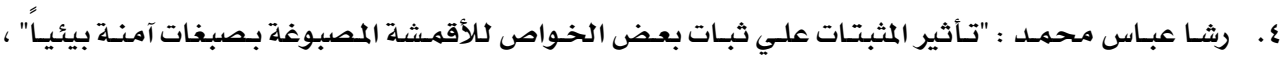

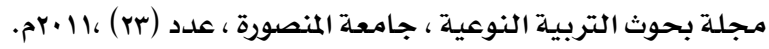




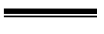

مجلة بحوث التربية النوعية - عدد شr - أبريل 10 r م

ه. ريهام مـصطفى محمـد وآخـرون : "تأثير اخـتلاف التراكيـب النسسجية مـع الصبـاغة بـصبغة طبيعيـة على

بعض الخـواص الطبيعيـة لكلأقهشة السـليلوزيـة " ، مجلـة علـوم وفنـون ، دراسـات وبحـوث ، جامعـة حلـوان ،

$\cdot$. 1 .

ج. صلاح منصور ومحمد الجمل : "قابلية صباغة أصناف الأقطان المصرية بصبغة البصل الطبيعيـة "، المجلـة المصرية للعلوم التطبيقية ،ب...rم.

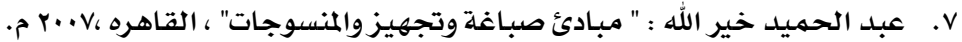

^. عزة عبد العزيزوصلاح منصور: " تحسين خواص الصباغة لبعض أصناف القطن المصري باستخدام صبغة

الكركم الطبيعية مـع المعالجة بالأنزيمات" ، معهد بحوث القطن ، مـركز البحوث الزراعية ،ه م. .بم.

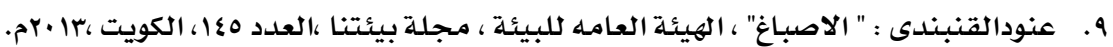

• 1 . لميـاء عبــ الفتـاح : " تـأثير عمليـات العنايـة علـى خـواص بعـض الأقهـشة المـصبوغة بـالـصبغات الطبيعيـة

وإمكانية استخدامها ِِف صناعة الملابس الجاهزة" ، رسـالة دكتوراه غير منشورة ، كليـة الاقتصـاد المنزلى ،

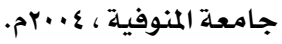

11. محمد أحمد عبد السلام : "تكنولوجيا إنتاج وتصنيع القطن" ، مكتبـة الشعب ، القاهرة ، •191 .

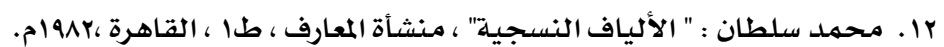

ما ـ مني عبد الهادي : " قابليـة حياكة أقمـشة التريكو ذات المطاطيـة العاليـة " ، مجلـة بحـوث التربيـة النوعيـة ،

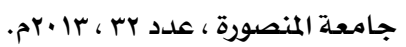

ع ا. نهى محمد عبده السيد : "استخدام الصبغات الطبيعية ِِّ طباعه أقمشة التريكو و استخدامها فى صسناعه

ملابس الأطفال" ، رسالة ماجستير غير منشورة ، كلية الاقتصاد المنزلي جامعة المنوفية ، ^ +.بrم.

10. نهى محمد عبده السيد : "تحسين الخواص اللونية لأقمشة الكتان المعالجة بالانزيمات والمصبوغه بصبغات

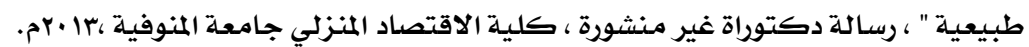

16. Ali Ahmad Khan and Others : "Extraction of natural dye from red calico leaves: Gamma ray assisted improvements in colour strength and fastness properties" , journal Dyes and Pigments, vol 103 p 50-54,2014.

17. Ashis Kumar : "Application of single and mixtures of red sandalwood and other natural dyes for dyeing of jute fabric: studies on colour parameters/colour fastness and compatibility" ,The Journal of The Textile Institute,Volume 100, Issue 7,p. 565-587.2009.

18. Ashis Kumar and Adwaita Konar: Dyeing of Textiles with Natural Dyes', Department of Jute and Fibre Technology, Institute of Jute Technology,University of Calcutta, India. http://www.intechopen.com.2011.

19.Emriye Akcakoca Kumbasar :" Natural Dyes" Publisher InTech Published online14, November, 2011. 
20. Fazal-ur Rehman and others : " Dyeing of $\gamma$-irradiated cotton with natural flavonoid dye extracted from irradiated onion shells (Allium cepa) powder , " journal Radiation Physics and Chemistry, vol 92 , p71-75, 2013.

21. Rattanaphol Mongkholrattanasit and Others:" Natural Dye from EucalyptusLeaves and Application for WoolFabric Dyeing by Using Padding Techniques". http://www.intechopen.com.Novemper 2011.

22. R.M Christie :"Environmental aspects of textile dyeing", extile institute http://books.google.com.sa/.2007.

23. SK.Sharma: Natural dyes, The Indian textile journal,1998.

24. Shahid Adeel and Others: "Dyeing of Cotton Fabric Using UV Irradiated Turmeric (Curcuma longa L.) as Natural Dye", Research Journal of Textile and Apparel vol 15,p71-76.2011.

25. Shahid Adeel and Others:" Influence of gamma radiation on the colour strength and fastness properties of fabric using turmeric (Curcuma longa L.) as natural dye, Radiation Physics and Chemistry, Volume 79, Issue 5, May 2010, Pages 622-625.

26. AATCC.16.(1971).

27. AATCC.15.(1973).

28. AATCC.61.(1975) .

29. AATCC.61.(1977) .

30. AATCC.68.(1993) .

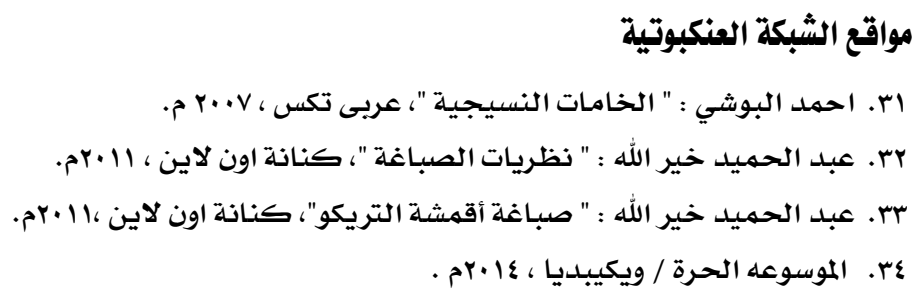

35. http://www.intechopen.com/ 


\section{Study quality colorimetric properties of some natural dyes on fabrics ( single jersey)}

\section{Abstract}

The current research aims to study the possibility of producing entirely natural fabrics using natural dyes to identify the quality of dyeing these dyes in dye fabrics (single Jersey), cotton and these pigments are (Turmeric -Hibiscus- green tea - cinnamon ) with use of environmentally safe stabilizers: ( aluminum sulfate - and magnesium sulfate).

Dyeing the weft knitted fabrics (single Jersey) cotton combed different combinations constructivism where used three count are : (20/ 1$24 / 1$ - 30/1) combed Knitting English numbering of Pakistani cotton , and three different lengths of thread ( $111.2-97.2-85.1 \mathrm{~m} / \mathrm{s}$ ).

Then properties were studied: (the intensity of the color - the color fastness of friction - color fastness to perspiration - color fastness to light) .

Better research samples combined sample was No. (7)20/1 , and the weight of $148 \mathrm{~g}$, and the stitch length 2.7 - using green tea dye ), where given the perfect space ( 817.02 ) and the coefficient of quality $(81.70 \%$ ), while less research samples were sample ( (1) 30/1 , and the weight of $85 \mathrm{~g}$, and stitch length 2.7- using dye turmeric), where given the perfect space (586.39) and the coefficient of quality ( $58.64 \%$ ). 